\title{
Most frequent molecular and immunohistochemical markers present in selected types of brain tumors
}

\author{
Romana Richterová ${ }^{1,2}$, Jana Jurečeková ${ }^{1}$, Andrea Evinová ${ }^{1}$, Branislav Kolarovszki², Martin \\ Benčo ${ }^{2}$, Július De Riggo ${ }^{2}$, Juraj Šutovský ${ }^{2}$, Silvia Mahmood ${ }^{1}$, Peter Račay ${ }^{1}$ and Dušan Dobrota ${ }^{1}$ \\ ${ }^{1}$ Department of Medical Biochemistry, Comenius University Bratislava, Jessenius Faculty of Medicine, Malá hora 4, Martin, \\ Slovak Republic \\ ${ }^{2}$ Department of Neurosurgery, Comenius University Bratislava, Jessenius Faculty of Medicine, University Hospital Martin, \\ Kollárova 2, Martin, Slovak Republic
}

\begin{abstract}
Tumors of brain tissue and meninges create a heterogeneous group with various biological behavior, therapy management and differing prognosis. Some of these do not require treatment, some can be cured by surgery and some are rapidly fatal despite treatment. Despite huge progress in tumor research, innovations in diagnostic tools and therapy, prognosis remains, in case of malignant tumor types, very serious. There has been an increased understanding of molecular abnormalities occurring in primary brain tumors. Genome-wide analyses of tumors have improved the knowledge in tumor biology. The aim of the research is to explain the oncogenesis features thus leading to the use of new therapeutic modalities in order to prolong survival rate of patients and at the same time providing satisfactory life quality. This article offers a short review of the basic genetic alterations present with some histological types of brain tumors.
\end{abstract}

Key words: Brain tumors - Glioma - Meningioma - Genetic alteration

\begin{abstract}
Abbreviations: CDK, cyclin dependent kinase; CNS, central nervous system; DCC, deleted in colorectal cancer gene; EGF, epidermal growth factor; EGFR, epidermal growth factor receptor; FGF, fibroblast growth factor; GFAP, glial fibrillary acidic protein; IDH, isocitrate dehydrogenase genes; IGF, insulin-like growth factor; IGFBP, insulin-like growth factor binding protein; IGFR, insulinlike growth factor receptor; $\mathrm{LOH}$, loss of heterozygozity; MDM2, murine double minute-2; MGMT, $\mathrm{O}^{6}$-methylguanine-DNA methyltransferase; NF2, neurofibromatosis type 2; PCNSL, primary central nervous system lymphoma; PDGF, platelet-derivated growth factor; PTEN, phosphatase and tensin homology; RB1, retinoblastoma gene; $\mathrm{SHH}$, sonic hedgehog pathway; STAT6, signal transducer and activator of transcription; TGF- $\alpha$, transforming growth factor $\alpha$; VEGF, vascular endothelial growth factor; VEGFR, vascular endothelial growth factor receptor; WNT, Wingless pathway.
\end{abstract}

\section{Introduction}

Intracranial tumors considerably contribute to morbidity and mortality in patients. These consist of cells whose differentiation and cell division spin out of control. Their etiology is multifactorial. The tumors take their origin as a result

Correspondence to: Romana Richterová, Department of Neurosurgery, University Hospital Martin, Kollárova 2, 03601 Martin, Slovak Republic

E-mail: romana.richterova@gmail.com of an accumulation of various genetic alterations which allow the cells to escape physiological regulatory mechanisms and their destruction by the immune system cells (Wrensch et al. 2002). Despite a huge amount of potential risk factors for tumorigenesis, only 3 of them had been verified: some hereditary syndromes (neurofibromatosis type 1 and 2, Turcot, Li-Fraumeni, Cowden syndrome, etc), radiation exposure (including therapeutic exposition) and severe immunosupression are confirmed as a risk factor of brain lymphomas. But these identified factors are responsible only for a small amount of tumors (Fisher et al. 2007; Bondy 
et al. 2008). Many risk factors remain unclear in the onset of oncogenesis. Recent research indicates that the immune system plays a role in both the development of and host defence against brain tumors (Albesiano et al. 2010; Charles et al. 2011). It is believed that among the molecular and immunological factor, also diet, environmental and personal exposition might play an important role in the etiopathogenesis of tumor development (Wrensch et al. 2002; Bondy et al. 2008; Curran and Bertics 2012).

\section{Molecular biological features of selected brain tumor types}

Cells might be deviated from normal cell cycle (proliferation, differentiation, cell death) by two types of genes - oncogenes and tumor suppressor genes. These genes spark oncogenesis by accumulating genetic lesions. Oncogenes, when activated, can cause cells to escape apoptosis and thus further proliferate themselves. The most common forms of genetic alteration in these genes are the amplification of genetic material and an activating mutation. It is dominant, as mutation of one allele is sufficient to express the function of the oncogene.

On the other hand, tumor suppressor genes and their protein products cause inhibition of cell growth. The most common genetic alterations in these genes are deletions (loss of genetic material) or inactivating (inhibitory) mutations. Mutant forms of tumor suppressor genes are recessive. Mutations on both alleles are required to abolish its function.

Table 1. Primary brain tumors in adults and their distribution according to histological classification (modified from CBTRUS 2000-2004)

\begin{tabular}{lc}
\hline Histological type & $\%$ \\
\hline Meningioma & 33.00 \\
Glioblastoma & 18.30 \\
Tumors of cranial nerves & 8.60 \\
Pituitarytumors & 8.00 \\
Hematological neoplasms & 2.80 \\
Anaplastic astrocytoma & 2.60 \\
Astrocytoma & 2.20 \\
Oligodendroglioma & 1.90 \\
Not specified malignant glioma & 1.60 \\
Ependymoma & 1.20 \\
Neuronal/glial tumor & 0.80 \\
Pilocytic astrocytoma & 0.60 \\
Craniopharyngeoma & 0.50 \\
PNET/medulloblastoma & 0.40 \\
Germ cell tumors & 0.20 \\
Others & 17.30 \\
\hline
\end{tabular}

Brain metastases are the most frequent tumors in intracranial localisation. The most frequent malignant primary brain tumors in adults are gliomas and primary central nervous system (CNS) lymphomas, most frequent benign tumors are meningiomas and pituitary adenomas (Table 1), (Wrensch et al. 2002; Louis et al. 2007; CBTRUS 2008).

\section{Gliomas}

Gliomas are the most common type of primary brain tumors (about 70-80\%), (Louis et al. 2007; Ricard et al. 2012). Gliomas can originate from neural stem cells, progenitor cells (Persson et al. 2010), or de-differentiated mature neural cells that transformed into cancer stem cells (Stiles and Rowitch 2008; Ricard et al. 2012). It is suggested that gliomas may arise from neuroepithelial stem cells (NEPs); some glioblastomas may rise from oligodendrocyte-type 2 astrocytes. NEP is a growth precursor for all cell types in the brain and spinal cord and possess the capacity for survival, self-renewal and uncontrolled cell division. Its growth is regulated by the epidermal growth factor (EGF) or fibroblast growth factor (FGF), (Nupponen and Joensuu 2006; Kozler et al. 2007).

Mutations of tumor suppressor genes lead to loss of function and overexpression of oncogenes occurring in oncogenesis. Various molecular abnormalities occur in gliomagenesis (Figure 1). The most frequently altered genes are: TP53, MDM2, CDKN1A, CDKN1B, CDKN2A, CDKN2B, p14 ${ }^{A R F}, C D K 4, C D K 6, R B 1$ (the retinoblastoma gene) and more.

The TP53 gene is localized on 17p13.1. The product of this gene is the tumor suppressor protein p53. TP53 is a critical tumor suppressor that restricts proliferation and cell growth following stress. This protein is known for its ability to induce cell cycle arrest, cell reaction to DNA damage, apoptosis, senescence, autophagy, cell differentiation and neovascularisation and cell death (Vousden and Prives 2009; Hede et al. 2011). Because of the crucial role of p53 as a tumor suppressor, TP53 is one of the most frequently mutated genes in human cancer cells (Iacob and Dinca 2009). The p53 and RB cell cycle and cell death signaling pathway is shown on Figure 1. Adult malignant astrocytoma was one of the first tumors shown to have frequent TP53 mutations (Nigro et al. 1989; Iacob and Dinca 2009). The dysfunction of TP53 disrupts the p14ARF pathway, delaying the process of apoptosis and further promoting genomic instability (Krakstad and Chekenya 2010). The most common positions of alterations are codons 175, 248 and 273 contributing substantially to the overall high incidence of alterations in p53's DNA-binding domain. Polymorphisms in codon 72 have been associated with susceptibility to human cancer. A possible association has 


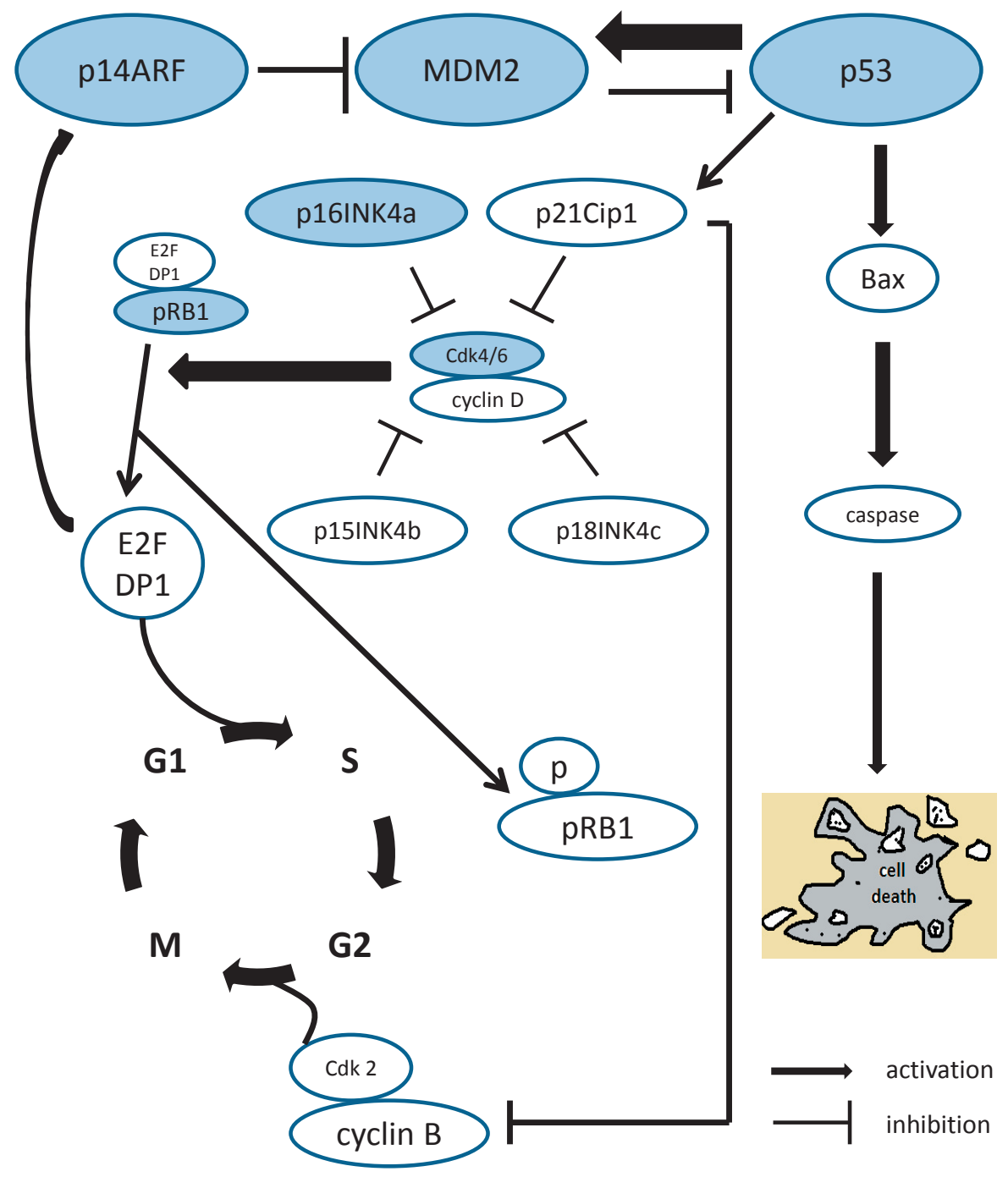

Figure 1. The tumor suppressor protein $\mathrm{p} 53$ and $\mathrm{RB}$ cell cycle and cell death signaling pathway. Alterations in this pathway cause inability of cells to undergo apoptosis and they proliferate. Proteins marked with full colour are most frequently altered in astrocytomas. MDM2, mdm2 TP53 binding protein homologue; RB, retinoblastoma. been found between TP53 Arg72Pro polymorphisms and susceptibility to brain tumors, particularly in high-grade astrocytomas (Parhar et al. 2005). Another study has failed to confirm this observation (Zhang et al. 2012). Loss of an allele on chromosome 17p and mutation of TP53 occur in one-third of all astrocytomas, but the mutation of TP53 is the most important in the formation of astrocytomas grade II (Hede et al. 2011; Wang et al. 2011). It also plays a role in their progression to secondary glioblastoma (shows a previous history of progression from lower-grade astrocytoma), but on the contrary, it is relatively rare (cca 10\%) in primary glioblastoma (Furnari et al. 2007; Ohgaki and Kleihues 2007) and pilocytic grade I astrocytoma (Hede et al. 2011). This fact helped to establish two different genetic pathways that lead to glioblastoma formation - primary and secondary glioblastoma (Ohgaki and Kleihues 2007; Hede et al. 2011). Protein p53 was shown to be a prognostic marker (Levidou et al. 2010). Recently, novel functions of p53 in stem cells have been found, these including suppression of pluripotency and inhibition of stem cell self-renewal (Zhao and Xu 2010).

MDM2 (murine double minute-2) is an oncogene located on chromosome 12q14.3-q15. The protein product of this gene is E3 ubiquitine ligase, it negatively regulates p53 and suppresses cell cycle arrest or apoptosis and also promotes cell survival and growth (Thomasova et al. 2012). MDM2 protein suppresses $\mathrm{p} 53$ 's transcriptional activity and targets p53 for proteasomal degradation (Wade et al. 2010). Amplification and overexpression of MDM2 excludes TP53 from having an effect on the cell cycle. Amplification of this gene is present in $10 \%$ of glioblastoma without a TP53 mutation (Hede et al. 2011). Overexpression of MDM2 plays an important role in glioma tumorigenesis, but does not seem to be involved in glioma progression (Wang et al. 2011). MDM2 is strongly expressed in many malignancies with wild type p53 as an alternate mechanism to disrupt the p53 
pathway in early cancer development (Eischen and Lozano 2009; Hede et al. 2011).

CDKN1A gene is located on chromosome 6p. The product of this gene is protein $\mathrm{p} 21$ whose transcription is regulated by the level of protein p53. Protein p21 is a member of the kinase inhibitor protein (KIP) family. It has a negative effect on the function of cyclin E/CDK2 (cyclin dependent kinase) and cyclin A/CDK2 complexes and activates cyclin D/CDK complexes. This protein has a huge effect on controlling cell proliferation by regulating binding to different CDK complexes (He et al. 2006). All exogenous effects that cause TP53 mediated cell cycle arrest or apoptosis induce transcription of protein p21. Amplification of this gene is frequent in all glial tumors (Walker et al. 2011).

CDKN1B gene is localized on chromosome 12p13.1-p12. The product of this gene is protein $\mathrm{p} 27$. This protein is also a member of the KIP family and has opposite effects on the function of different $\mathrm{CDK}$ complexes. It inhibits the function of cyclin E/CDK2 and cyclin A/CDK2 complexes and it seems to activate cyclin D/CDK complexes (He et al. 2006). Frequent binding of p 27 to cyclin D/CDK complexes was found in proliferating cells. On the other hand, in $\mathrm{G}_{1}$-arrested cells p27 was found in complexes with cyclin E/CDK2. The crucial role for cell cycle progression seems to depend on the competition for binding of p27 between cyclin D/CDKs and cyclin E/CDK2 complexes. High expression of p27 is present in diffuse astrocytoma (grade II), low expression is seen in malignant gliomas and some carcinomas, and very low expression in anaplastic astrocytomas and glioblastoma (Yue et al. 2012).

CDKN2A and CDKN2B genes are located on chromosome $9 \mathrm{p} 21$. Their products are proteins p16 and p15 acting as inhibitors of CDK (mainly CDK4 and CDK6), (Liu et al. 2010). Proteins p16 and p15 inhibit the phosphorylation of $\mathrm{RB} 1$ protein by binding to cyclin $\mathrm{D}$ and thus preventing its interaction with CDK4 and CDK6. Mutations of these genes are connected with a higher risk of glioma development (Shete et al 2009; Wrensch et al 2009). Homozygous deletion in CDKN2A, results in suppression of RB1 protein function via elevated CDK $4 / 6$ activity, and is detectable in almost $50 \%$ of gliomas and also the loss of expression has been linked to poor prognosis (Simon et al. 2006, 2010; Goldhoff et al. 2012). Polymorphisms in CDKN2A/CDKN2B genes are not connected with tumor grade and prognosis (Simon et al. 2010). Regulation of $\mathrm{p} 16 / \mathrm{p} 14^{\mathrm{ARF}}$ is important for sensitivity to ionizing radiation, the only environmental factor strongly connected with gliomagenesis (Liu et al. 2010).

Gene $p 14^{A R F}$ is also located on locus 9p21. Its product protein $\mathrm{p} 14^{\mathrm{ARF}}$ inhibits degradation of $\mathrm{p} 53$ mediated by $M D M 2$. Upregulation of $p 14^{A R F}$ increases $p 53$ level which in turn increases the sensitivity of p53 pathway and induces cell cycle arrest and apoptosis (Liu et al. 2010). Germline mutations of $\mathrm{p} 14^{\mathrm{ARF}}$ have been reported to cause melanoma-astrocytoma syndrome (Randerson-Moor et al. 2001).

Both CDK4 gene (localized on chromosome 12q14) and CDK6 gene (7q21-22) products CDK4, CDK6 proteins have a catalytic kinase activity. They produce complexes with cyclin $\mathrm{D}$ and are inhibited by proteins $\mathrm{p} 15$ and p16. CDK6, an oncogene, is required for proliferation and viability of tumor tissue (Wiedemeyer et al. 2010). Overexpression of all CDK proteins can inhibit function of p15 and p16 (inhibitors of CDK), (Malumbres and Barbacid 2009). Amplification of CDK4 and CDK6 is present in $15 \%$ of high-grade gliomas (Wiedemeyer et al. 2010).

The retinoblastoma gene ( $R B 1$ ) is located on chromosome $13 \mathrm{q} 14.2$. Its product is the RB1 protein which is the final point of kinase activities of CDK4/CDK6-cyclin $\mathrm{D}$ complexes. RB protein controls entry into the cell cycle, it acts as gatekeeper to S-phase entry. This protein is normally not phosphorylated and it is associated with the transcription factor E2F. RB with E2F acts as a silencing complex and restricts access to transcription factors. Phosphorylation of RB1 protein leads to the release of transcription factor E2F. Such altered conformation allows access to cdk2 during S-phase which produces additional phosphorylation and further inhibiting E2F binding (Goldhoff et al. 2012). This disruption of RB/E2F allows transcription of crucial genes required for cell cycle entry. Aberrations of $R B$ pathway are common in glioblastoma and play a critical role in gliomagenesis and tumor progression for lower-grade astrocytomas (Chow et al. 2011 ). These alterations are present in $80 \%$ of all primary glioblastoma (The cancer genome atlas 2008). Alteration of this gene is present in one-third of high-grade astrocytomas. Mutated $R B 1$ has the same effect as the amplification of $C D K 4 / C D K 6$ or mutation of $C D K N 2 A / C D K N 2 B$, nevertheless these genetic alterations are never present together. This information demonstrates that oncogenesis of grade III and grade IV astrocytomas proceeds by only one of these alternative genetic pathways. Alterations in $R B 1$ expression have been associated with increased tumor proliferation and decreased survival (Kim et al. 2011). RB1 may have a more direct correlation with prognosis in lower-grade (II, III) astrocytomas than in glioblastoma (Kim et al. 2011). The RB pathway is nearly universally inactivated in human cancers, including glioblastoma (Wiedemeyer et al. 2010).

Deleted in colorectal cancer gene (DCC) is located on chromosome 18q21.3 and its product is the DCC protein. This transmembranous protein is expressed in high quantities in the nervous system. Products of this gene create part of the receptor for netrin 1 . Netrins play important roles in direct cell and axon migration during neural development (Rajasekharan and Kennedy 2009). These proteins are also expressed in adult tissues, although their function is not yet 
known. DCC induce apoptosis and cell cycle arrest in $G_{2}$ point and it is also required for chemoattraction to netrin-1 slowing the rate of spontaneous cell migration (Jarjour et al. 2011). An anti-oncogenic function had been suggested for DCC, although netrin signaling disruption contributing to tumorigenesis is still poorly understood (Jarjour et al. 2011). Immunohistochemical examinations demonstrate that the expression of DCC decreases in many malignancies, including the most high-grade gliomas and also during progression from low-grade astrocytomas to glioblastoma. This shows that DCC is connected with the formation of secondary glioblastoma, but not with the formation of primary glioblastoma (Kozler et al. 2007; Jarjour et al. 2011).

Phosphatase and tensin homology PTEN (also called MMAC1, TEP-1) is a tumor suppressor gene on chromosome $10 \mathrm{q} 23.3$. The product of this gene is a lipid phosphatase that counteracts the effect of PI3K signaling, thereby negatively controlling the activation of this pathway (Figure 2 ). This gene is mutationally or transcriptionally inactivated in many tumor types, including astrocytomas (Bleeker et al. 2009). Germinal PTEN mutations were seen in some autosomal hereditary diseases, such as Cowden disease, Bannayan-Zonana syndrome, etc. Monosomy of chromosome 10 is frequently seen in glioblastoma, but rarely in low-grade astrocytoma. Loss of function of this tumor supressor gene is present in both, primary and secondary glioblastoma (Hede et al. 2011). PTEN is mutated or lost in $60-70 \%$ of high-grade glioma (Dey et al. 2008) and is associated with poor prognosis (Walker et al. 2011). After the exposure to ionizing radiation, PTEN acts as a critical determinant of cell fate between senescence and apoptosis (Lee et al. 2011).

Paternally expressed gene 3 (PEG3) is located on 19.chromosome. $P E G 3$ is an imprinted gene that is expressed mainly during embryogenesis and in adult ovary, testis, muscle and brain (Jiang et al. 2010). The low gene expression was confirmed in glioblastoma and its high expression was observed in oligodendrogliomas. Results show that abnormal regulation of PEG3 induces formation of some gliomas and also plays an important role in tumorigenesis (Otsuka et al. 2009).

Growth factors also play an important role in oncogenesis as mutations of these factors are frequently present in gliomas.

Epidermal growth factor (EGF) gene is located on chromosome 4q25. EGF binds to EGFR inducing a dimerisation of one or several members of the EGFR family (ErbB 1-4), activating several thyrosine kinases and other downstream signal molecules promoting transcription in the cell nucleus (Sjöström et al. 2010). In a small study including only 42 patients, poor survival of glioblastoma patients with functional polymorphism $61 \mathrm{~A} / \mathrm{G}$ located in the EGF promoter was observed (Bhowmick et al. 2004). But 2 other studies with a bigger group of patients failed to replicate the initial observation (Costa et al. 2007; Vauleon et al. 2007).

Epidermal growth factor receptor (EGFR) gene is located on chromosome 7p12. EGFR is a transmembranous receptor responsible for communication with its extracellular ligands (EGF and TGF- $\alpha$ (transforming growth factor $\alpha$ )) and for transmission of their signalisation within the cell. EGFR is the most frequently amplified gene in astrocytomas (approximately one-third of glioblastoma cases, less seen in anaplastic astrocytomas). EGFR is closely connected with tumor proliferation, metastasis, apoptosis, angiogenesis, and sensitivity to therapy and drug resistance (De Luca et al. 2008). Mutations in the EGFR gene are associated with early relapses and poor prognosis (Hu et al. 2013). Expression of EGFR is higher in high-grade and poorly-differentiated gliomas and together with amplification of EGFR is correlated with tumor progression (Hoelzinger et al. 2005; De Luca et al. 2008; Hofer and Lassman 2010; Hu et al. 2013). More than $50 \%$ of glioblastomas have a mutation of EGFR which can exist in 3 variations: EGFR $v I I I, \delta E G F R$ and de27EGFR (deletion, loss of exons 2-7 of mRNA strand). The $\delta$ EGFR promotes tumorigenesis of glioblastoma cells in vivo by increasing cellular proliferation (Narita et al. 2002), decreasing cellular apoptosis (Puputti et al. 2006) and promoting tumor cell invasion (Lal et al. 2002). Amplification and specific mutation of EGFR (de2-7EGFR) is typical for primary glioblastoma. Primary glioblastoma with this mutation simultaneously have monosomy of chromosome 10. Amplification in glioblastoma is present also without homozygote deletion or mutation of PTEN (simultaneously present in $20 \%$ of primary glioblastoma), but in most cases it is associated with CDKN2A deletion (Kozler et al. 2007). It has been suggested that alteration of EGFR alone is not enough to cause tumorigenesis but another alteration in protein RB1 pathway is necessary to cause tumor formation (Figure 2).

Platelet-derivated growth factor (PDGF) exists as five types of dimers consisting of 4 types of polypeptides, each encoded by a different gene - A, B, C and D. PDGFA (gene $P D G F A$, localized on 7p22), PDGFB (gene PDGFB, localized on 22q13.1), PDGFC (gene PDGFC, localized on 4q32), and PDGFD (gene PDGFD, localized on $8 \mathrm{q} 11$ ). There are only 2 receptors: PDGFR- $\alpha$ (gene PDGFRA on chromosome $4 \mathrm{q} 11-\mathrm{q} 13$ ) and PDGFR- $\beta$ (gene PDGFRB on chromosome 5q31-q32). Overexpression of PDGF and PDGFR are frequently present in astrocytoma (mainly glioblastoma) and medulloblastoma, but amplification is rare (Furnari et al. 2007). Deletion of $17 p$ is often connected with PDGFR- $\alpha$ overexpression (Kozler et al. 2007). PDGFR pathway aberrations are mainly associated with secondary glioblastoma (Puputti et al. 2006) (Figure 2).

Insulin-like growth factor (IGF) plays a role in the regulation of tumor cell biology. The IGF system is comprised 


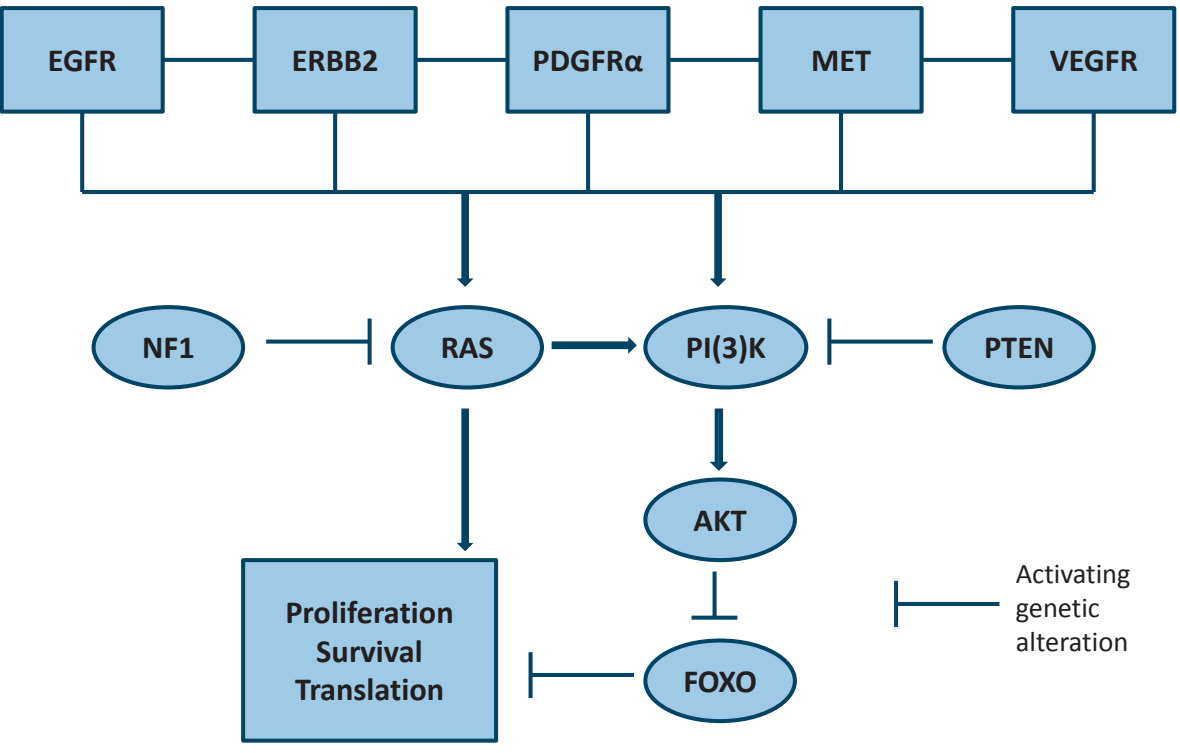

Figure 2. Frequent genetic alteration in RTK/RAS/PI(3)K pathway. Most frequently altered genes are PTEN, NF1 and EGFR genes. AKT, protein kinase B; EGFR, epidermal growth factor receptor; ERBB2, receptor tyrosine-protein kinase erbB-2; FOXO, forkhead box proteins; MET, hepatocyte growth factor receptor; NF1, neurofibromatosis type 1; PDGFRa, platelet-derivated growth factor receptor $\alpha$; PI3K, phosphoinositol 3 kinase; PTEN, phosphatase and tensin homology; RAS, protein superfamily of small GTPases; RTK, receptor tyrosine kinase;VEGFR, vascular endothelial growth factor receptor. of two ligands: IGF1 (gene located on 12q23.2) and IGF2 (somatomedin A, located on 11p15.5) and its receptors: IGF1R (gene located on 15q26.3) and IGF2R (6q26), six binding proteins (IGFBP 1-6) and various IGFBP-related peptides. IGF1 is a major physiological mediator of growth hormone and has a strong influence on cell proliferation and differentiation. It also inhibits apoptosis by blocking the initiation of the apoptotic pathway. Its receptor IGF1R is involved in malignant transformation processes. IGFBPs modulate interactions between IGF and IGFR. IGFBP3 (located 7p13-p12) which acts as an apoptotic agent, inhibits IGF1 activity and has growth promoting effects (Lön et al. 2008). IGF1, IGF2 and IGF1R genes have been reported to be amplified in glioma as well as in other cancers (Furstenberger and Senn 2002; Renehan et al. 2004; Russo et al. 2005). Polymorphism of $I G F 1 R$ indicates a possible association with glioma risk (low-grade). No connection between IGF polymorphisms and glioblastoma risk has been found (Lön et al. 2008).

Regarding other growth factors and their receptors, astrocytoma genesis is also associated with the overexpression of FGF, ( $a F G F$ - chromosome 5q31.3-q33.2, bFGF - chromosome 4q27-q25) and vascular endothelial growth factor - VEGF (receptor 1 - chromosome 13q12, receptor 4 - chromosome 5q33-qter). Level of expression of VEGF is directly correlated with the occurrence of bleeding into the tumor. Although EGFR and VEGFR are heavily activated in glioblastoma, agents targeting these showed disappointing results in clinical trials (Brown et al. 2008; Norden et al. 2008).

From other types of genes connected with gliomagenesis, the most frequently observed alterations are: glutathione
S-transferases genes, isocitrate dehydrogenases genes and epigenetic changes of methylguanin O-methyltransferase gene.

Glutathion S-transferases (GST) genes: GSTP1 (location 11q13), GSTM1 (1p13.3), GSTT1 (22q11.23), GSTO1 (10q25.1). GSTs are phase II biotransformation enzymes that function on the detoxification of a wide range of exogenous agents including carcinogens. They are responsible for glutathion conjugation of alkylators and scavenging of free radicals generated by radiation (Kilburn et al. 2010). GSTs provide enzymatic and non-enzymatic functions and are involved in many important cellular processes, such as: stress response, cell proliferation, apoptosis, oncogenesis, tumor progression and drug resistance (Lo and Ali-Osman 2007). Genetic variations in these genes are important in determining the response to carcinogenes. GST polymorphisms may result in altered or absent enzyme activity and have been associated with survival rate in cancer patients. Results of recent studies suggested a relationship between brain tumor incidence with GSTM1 null genotype but not with GSTT1 or GSTP1 gene variants (Pinarbasi et al. 2005). Other studies observed no association between GST and the related enzyme polymorphisms and adult brain tumor risk (Schwartzbaum et al. 2007). Another study has shown a longer survival in patients with GSTP1 and GSTM1 polymorphisms in patients with grade III gliomas. These patients also had an increased risk of adverse events resulting from chemotherapy that primarily comprised nitrosourea alkylating agents (Okcu et al. 2004). GSTs also determine drug resistance and response of cancer patients to therapy (Lo and Ali-Osman 2007).

Isocitrate dehydrogenase genes IDH1 (located 2q33.3) and IDH2 (located 15q26.1). IDHs (IDH1, IDH2 and IDH3) are 
enzymes involved in the citric acid cycle that catalyze the oxidative decarboxylation of isocitrate to a a-ketoglutarate while reducing $\mathrm{NADP}^{+}$to $\mathrm{NADPH}\left(\mathrm{NAD}^{+}\right.$to $\mathrm{NADH}$ in the case of IDH3). A critical structure of IDH1 in the enzymatic interaction with the substrate isocitrate is the arginine 132 (R132), an identical role played by R172 in IDH2. The mutations of these genes are missense substitutions which lead to reduction of enzymatic activity of the encoded protein (Yan et al 2009; Pusch et al. 2011). Mutations of R132 result in a greater than $80 \%$ enzyme activity reduction compared with the wild type (Zhao et al. 2009). IDH genes were found to have mutations mainly in tumors that have evolved from low-grade gliomas (secondary glioblastoma), (Ichimura et al. 2009; Jha et al. 2011; Toedt et al. 2011), on the other hand, they are rare in primary glioblastoma $(7 \%)$ and pediatric glioblastoma (11\%), (Kim and Liau 2012). The IDH mutations are found across different molecular and histologic brain tumors subtypes (diffuse astrocytoma, oligodendroglioma, secondary glioblastoma, etc.) suggesting that there are early genetic alterations in tumorigenesis and they occur early in the development of a glioma from the stem cell that can give rise to both astrocytes and oligodendrocytes (Yan et al. 2009). Within the group of $I D H 1$ or $I D H 2$ mutated anaplastic astrocytomas and glioblastomas, $80 \%$ of this tumors also had mutations of TP53, but only 3\% had alterations in PTEN, EGFR, CDKN2A or CDKN2B. On the contrary, anaplastic astrocytomas and glioblastomas with wild type $I D H$ genes had a few TP53 mutations (18\%) and more frequent alterations of PTEN, EGFR, CDKN2A or CDKN2B (74\%), (Parsons et al. 2008; Ichimura et al. 2009; Yan et al. 2009). This fact indicates that IDH mutations occur more likely in secondary glioblastomas. One study identified the mutations that affected amino acid 132 of IDH1 in more than $70 \%$ of WHO grade II, III astrocytomas, oligodendrogliomas and secondary glioblastomas (Yan et al. 2009). Tumors without IDH1 mutations often had mutations affecting the analogous amino acid (R172) of the IDH2 gene. Tumors with such mutations have distinctive genetic and clinical characteristics and these particular patients had a better outcome than those with wild-type $I D H$ genes. This makes mutation of $I D H 1$ a novel prognostic factor in gliomas (Balss et al. 2008; Parson et al. 2008; Weller et al. 2009; Yan et al. 2009). On the other hand, a study conducted by Parson et al. found IDH1 mutations in approximately 12\% of glioblastoma (Parson et al. 2008). Explanation for this finding could be that the authors did not divide primary from secondary glioblastoma in there study. Within the group of primary glioblastomas, IDH1 mutations are rare and create a prognostically favorable subgroup (Weller et al. 2009).

The MGMT gene codes for a protein with alkyltransferase activity - $\mathrm{O}^{6}$-methylguanine-DNA methyltransferase (MGMT), a DNA-repair enzyme, which causes tumor resistance to alkylating and methylating agents (e. g. temozolo- mide). Activity of this enzyme is regulated by a promoter. Methylation of this promoter area of MGMT results in its inactivation. Weller et al. found MGMT promoter methylation in $44 \%$ of glioblastoma patients. Prolongation of progression-free survival was observed in patients treated with temozolomide, but not in patients receiving radiotherapy alone as their first-line treatment (Weller et al. 2009). Another author states that methylation of MGMT promoter in tumor tissue is associated with longer survival regardless of the therapy method used (Hegi et al. 2005). MGMT promoter hypermethylation is associated with prolonged progression-free survival and overall survival in patients with glioblastoma treated with alkylating agents (e.g. temozolomide), (Hegi et al. 2005; Herrlinger et al. 2006; Glas et al. 2009). Methylation status of the MGMT promoter is clinically the most relevant molecular parameter (Weller et al. 2009) and has been used as a biomarker to predict the sensitivity of gliomas to DNA alkylating chemotherapeutics (Von Deimling et al. 2011). Expression of MGMT is not associated with tumor grade (Hu et al. 2013).

According to WHO classification of brain tumors there are four main types of gliomas: astrocytomas, oligodendrogliomas, mixed oligoastrocytomas and ependymomas (Louis et al. 2007).

\section{Astrocytoma}

According to WHO classification (Luis et al. 2007) in order of increasing anaplasia, types of astrocytomas usually include: pilocytic astrocytoma (grade I), diffuse astrocytoma (grade II), anaplastic astrocytoma (grade III) and glioblastoma (grade IV). Low grade astrocytomas can progress to higher malignancy grade, leading to the formation of secondary glioblastoma, as opposed to the frequent primary glioblastomas (Ricard et al. 2012). High-grade astrocytomas are grade III and grade IV astrocytomas.

Diffuse infiltrative astrocytomas are tumors of astrocyte origin. Except pilocytic astrocytoma which has different behavior and is demarcated, other astrocytic tumors grow unbounded (Ricard et al. 2012). Astrocytomas spread along tracts in the white matter, then the tumor cells infiltrate cerebrospinal fluid and vessels between duplications of the meningeal layers. Healthy cells are unable to move in the white matter. Astrocytoma cells interact with the elements of structural proteins of the extracellular matrix to further promote their invasiveness. This way of spreading of tumor cells is induced by the activation of receptors and growth factors - integrins and proteins - DCC (deleted in colorectal cancer), hyaluron receptors CD44, RHAMM (receptor for hyaluronan mediated motility), BEHAB (brain enriched hyaluronan binding ), ontogenetic protein SPARC (secreted protein, acidic and rich in cysteine), receptors of PDGF, TGF- $\alpha$, EGFR and bFGF (Kim C. et al. 2011; Sciaccaluga 
et al. 2013; Viapiano et al. 2008). Interaction of the extracellular matrix proteins with activated growth factors and their receptors happen as a result of genetic alteration (mutation, deletion, overexpression or amplification). Border of the tumor plays the crucial role in invasion. There is also a localized migration by an activating protein - tenascin (Mustafa et al. 2012).

Formation and progression of tumor is always accompanied by angiogenesis. Tumor cells in an increased proliferative state need a greater oxygen supply in order to grow (GilGil et al. 2013). Angiogenic switch is triggered by hypoxia and starts with the up-regulation of vascular endothelial growth factor - VEGF (Mustafa et al. 2012). Microvascular proliferation and increase of vascularity in malignant gliomas is caused not only by increased angiogenesis, but also by remodelation of vessel wall and by activation of endothelial precursor cells with tha capacity to form de novo blood vessels - vasculogenesis (Li Calzi et al. 2010). Angiogenesis is mediated by the release of proangiogenic factors (e.g. VEGF, bFGF, angiopoietins 1-4), by endothelial, stromal and tumor cells, by the binding of these factors to their corresponding thyrosine kinase receptors such as: VEGF receptor (VEGFR-1, VEGFR-2 and VEGF-3), Tie-1, Tie-2, PDGFR- $\beta$, c-met and integrins (Tchaicha et al. 2011; Mustafa et al. 2012; Fagiani and Christofori 2013). These receptors are up-regulated on the surface of the tumor vessels and the tumor itself generates ligands for these receptors (Kozler et al. 2007). VEGF plays the most important role for angiogenesis in the tumor, providing increased vascular permeability and lymphangiogenesis (Gil-Gil et al. 2013). It also increases permeability of the blood-brain barrier and participates in the formation of brain edema. VEGF is also produced by tumor cells and the amount of VEGF produced depends on the grade of the tumor - a higher VEGF production was observed in association with higher grade tumors (Saharinen et al. 2011). VEGF in conjunction with angiopoietin 2, promotes neovascularisation. Tie- 2 receptor triggers capillary remodelling. In case of tumor progression there is increased expression of this receptor by endothelial cells (Fagiani and Christofori 2013). Angiopoietin 4 promotes tumor angiogenesis and glioblastoma progression (Brunckhorst et al. 2010). Another receptor involved in capillary remodelling is PDGFR- $\beta$ (Tchaicha et al. 2011).

Apoptosis as programmed cell death is important for the regulation of cell population and the balance between proliferation and cell growth on one side and cell death on the other side (Lockshin and Zakeri 2007). It plays a key role in central nervous system development, immune regulation, brain tumor development and also degenerative diseases (Mellai and Schiffer 2007). Resistance to apoptosis contributes to carcinogenesis and tumor progression. Since most of the current anticancer therapy regimes primarily act by activation of cell death pathways, including apoptosis, in cancer cells this adaptive stress response promotes the development of acquired resistance (Fulda 2010). Temozolomide, frequently used in glioma chemotherapy, induces apoptosis and autophagy in glioma cells. Necrosis is only marginally induced (Knizhnik et al. 2013). The same stimulus can elicit both, necrosis and apoptosis, depending on the intensity of the initial insult and on preservation or loss of energy production in the cell (Mellai and Schiffer 2007). The apoptosis pathway plays a role on proteins, such as: p53, p21, $\mathrm{Bcl}-2$, Bax, caspases etc. Other than expected, apoptosis was demonstrated in gliomas, with an increasing frequency from low grade to glioblastoma and was related to shorter survival. However, apoptotis index did not predict recurrence in astrocytomas (Mellai and Schiffer 2007). Inability to undergo apoptosis as a consequence of p53 inactivation might play a role in brain tumor development. Tumor cells escaping apoptosis have damaged DNA leading to an accumulation of mutations and, therefore, tumor progression (Krakstad and Chekenya 2010).

Low-grade astrocytomas often show loss of heterozygozity (LOH) of 22q and gain of chromosome 7 and amplification of 8q (Reifenberger and Collins 2004). Cca 40\% of high-grade astrocytomas show deletion on chromosome 19q. In 20-30\% of gliomas there is a $\mathrm{LOH}$ on chromosome 22q. It is suggested that some unknown tumor suppressor, which plays a role in the early stages of astrocytoma genesis, is localized on this chromosome (Kozler et al. 2007). Progression from low-grade to anaplastic astrocytoma and formation of secondary glioblastoma is connected with deletions on chromosomes 6, 9p, 11p, 17p, 13q, rarely with an amplification of 12q (Kozler et al. 2007; Walker et al. 2011). On the other hand, $\mathrm{LOH}$ on $10 \mathrm{p}, 10 \mathrm{q}$ is common in primary glioblastoma (Walker et al. 2011) (Figure 3).

\section{Oligodendroglioma}

Oligodendrogliomas originate from differentiated oligodendrocytes (oligodendroglial cells) or in immature glial precursor cells. Besides glioblastoma and astrocytomas, oligodendrogliomas represent the third most frequently encountered type of glial tumors and constitute $2.5 \%$ of all primary brain tumors (Ohgaki 2009). According to the WHO grading there are two forms of oligodendrogliomas - oligodendroglioma (grade II) and anaplastic oligodendroglioma (grade III), (Engelhard et al. 2003; Louis et al. 2007). Unlike other brain tumors, oligodendrogliomas very rarely metastasize to other locations, such as lung, liver, bone and cervical lymph nodes (Volavsek et al. 2009).

Genetic alterations of oligodendrogliomas are different from astrocytomas alterations. No specific immunohistochemical markers for these tumors exist. The most common genetic alteration in this type of tumor is a deletion at chromosomal loci $1 p$ and $19 q$. LOH of $19 q$ is found in $50-80 \%$ 


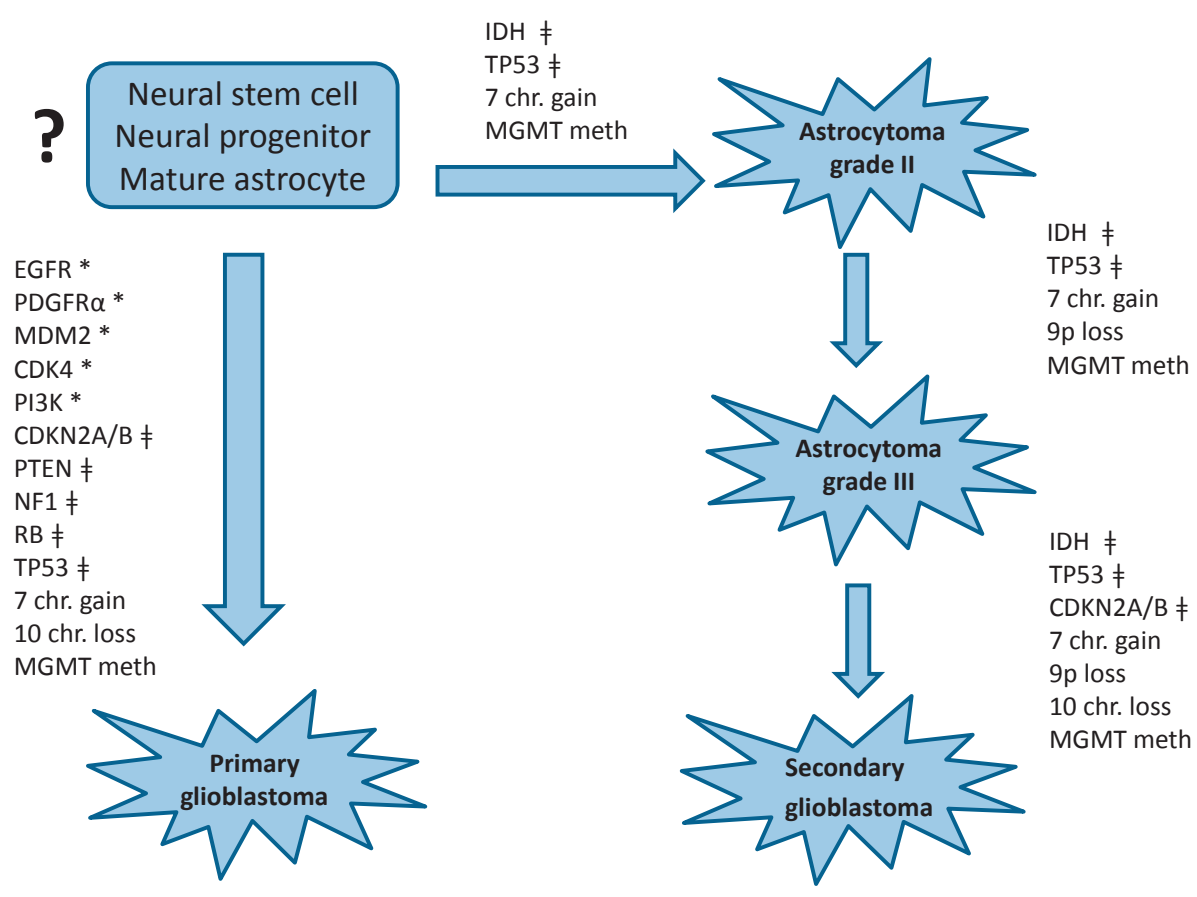

Figure 3. Gene and genomic regions involved in the biology of astrocytomas and primary and secondary glioblastoma. CDK4, cyclin dependent kinase 4; CDKN2A/B, cyclin dependent kinase inhibitor 2A/B; EGFR, epidermal growth factor receptor; IDH, isocitrate dehydrogenase; MDM2, mdm2 TP53 binding protein homologue; MGMT, O6-methylguanin DNA methyltransferase; meth, methylation; NF1, neurofibromin 1; PDGFR $\alpha$, platelet derived growth factor receptor $\alpha$; PI3K, pphosphoinositide 3 kinase; PTEN, phosphatase and tensin homologue; RB, retinoblastoma; TP53, tumor suppresor protein 53; * gain of function through amplification or mutation; $\neq$ homozygous deletion or mutation.

of oligodendrogliomas, $\mathrm{LOH}$ of $1 \mathrm{p}$ in cca $70 \%$ (Van den Bent 2004). Tumors with $\mathrm{LOH}$ on $1 \mathrm{p}$ also have $\mathrm{LOH}$ on $19 q$, what exert to their synergetic effect. A combined loss of $1 p$ and $19 q$ identifies a group of good tumor prognosis (Giannini et al. 2008; Velnar et al. 2009). Moreover, other studies showed more favourable survival in patients with tumors with combined loss of $1 p$ and $19 q$ also when treated with radiotherapy only (Van den Bent et al. 2006; Cairncross et al. 2006; Kouwenhoven et al. 2009). Pediatric oligodendrogioma only rarely exhibit chromosomal abnormalities (Stupp and Hegi 2007).

Only a small amount of tumors have mutations or deletions in the CDKN2C gene on 1p32. The TP53 mutation is present only in $10-15 \%$ of these tumors. This mutation occurs in tumors without $1 \mathrm{p}$ and $19 \mathrm{q}$ loss. These tumors are histologically anaplastic or mixed oligoastrocytomas and they express poor chemosensitivity (Ducray et al. 2008). Patients with TP53 mutations (and intact 1p 19q chromosomes) have only $33 \%$ efficacy rate with chemotherapy treatment. On the other hand, $100 \%$ response rate was observed in patients with 1p 19q codeletion and intact TP53 (Mueller et al. 2002).

Tumor cells are under influence of growth factors and the expression of their receptors. The most important receptors are EGFR and PDGF/PDGFR (Riemenschneider et al. 2004). VEGF and its receptors play an important role in angiogenesis. Overexpression of EGFR was observed in $50 \%$ of oligodendrogliomas, overexpression of other growth factors is less frequent (Stupp and Hegi 2007).

Anaplastic oligodendrogliomas may evolve from a lowgrade oligodendroglioma, becoming more anaplastic over time, or present de novo. They have the same genetic alterations as grade II (deletion on 1p and 19q) and also deletions on chromosomes 9 and 10, which accompany malignant progression also in other astrocytic tumors (Stupp and Hegi $2007)$. In $25 \%$ of cases of anaplastic oligodendrogliomas, a homozygous deletion on CDKN2A has been observed. Mutation of PTEN (frequently present in astrocytomas) is very rare. Multiple deletions are seen also on other chromosomes, for example 4, 6, 11, 15 and 18. Anaplastic oligodendrogliomas with deletion on chromosomes 10 and 9 and with amplification on chromosome 7 usually do not have typical deletions on $1 \mathrm{p}$ and $19 \mathrm{q}$ (Stupp and Hegi 2007). An average amount of chromosomes with lesions are higher in grade III then in grade II and this confirms the hypothesis that malignant transformation is connected with growing amount of genetic alterations (Mueller et al. 2002; Kozler et al. 2007).

Oligoastrocytomas, although classified separately, are heterogenous tumors with molecular features similar to oligodendrogliomas or astrocytomas. Some oligoastrocytomas show $\mathrm{LOH}$ on $1 \mathrm{p}$ and $\mathrm{LOH}$ on $19 \mathrm{q}$ - thus genetically resembling oligodendrogliomas, whereas $30 \%$ show mutations in the TP53 gene or LOH on 17p suggesting a relation to astrocytomas. Significantly, LOH on $1 p$ and $\mathrm{LOH}$ on $19 \mathrm{q}$ are inversely associated with TP53 mutation (Mueller et al. 2002). Amplification of EGFR is more frequent in oligoastrocytomas than in oligodendrogliomas. Tumors with this amplification have overal survival similar to patients with glioblastoma (Kouwenhoven et al. 2009) (Figure 4). 


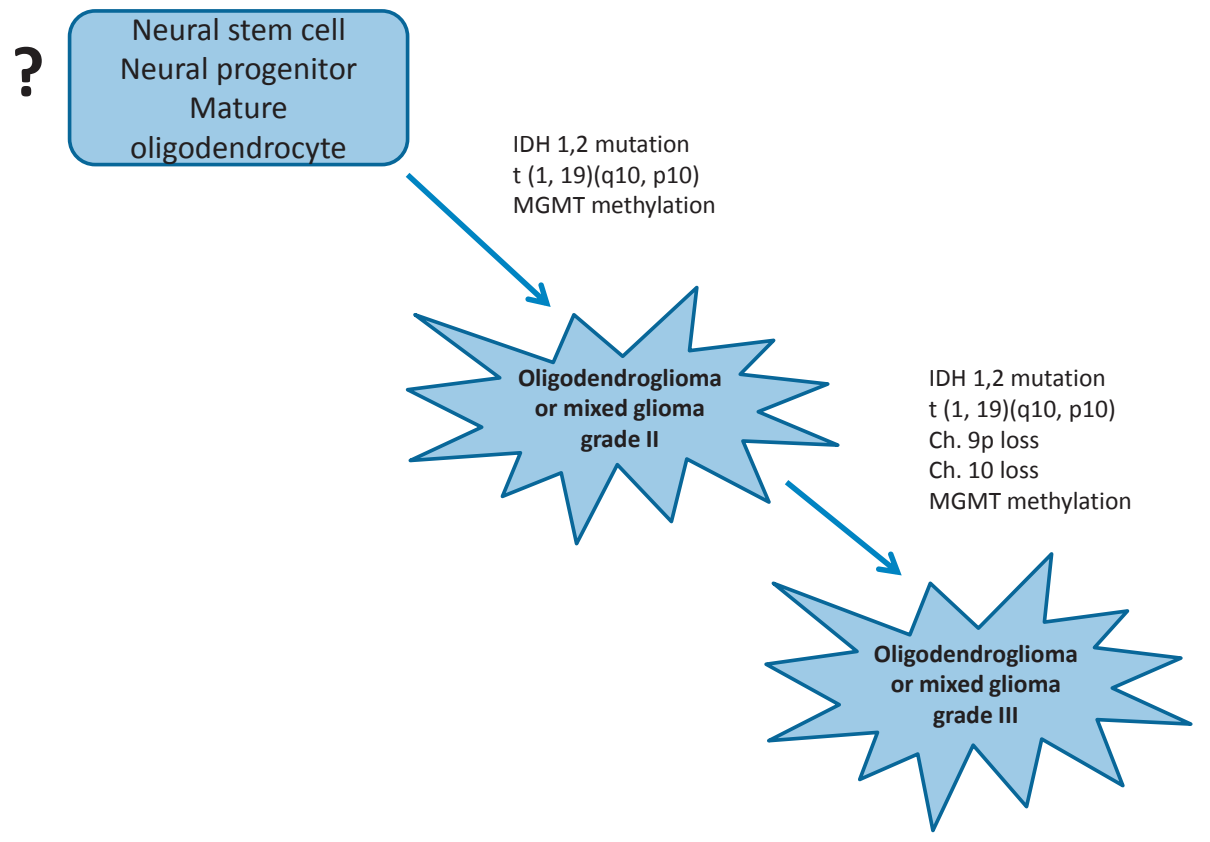

Figure 4. Gene and genomic regions involved in the biology of oligodendrogliomas and mixed gliomas (oligoastrocytomas). IDH, isocitrate dehydrogenase; MGMT, O6-methylguanin DNA methyltransferase.

\section{Ependymoma}

Ependymoma is the third most common pediatric brain tumor (Kilday et al. 2009). Ependymomas grow from ependymal cells which cover the internal layer of cerebrospinal fluid pathways (Yao et al. 2011). Most of the ependymomas in children occur intracranially, whereas adult cases predominantly occur within the spinal cord (Kilday et al. 2009). There are four known forms of ependymoma: subependymoma (grade I), myxopapillary ependymoma, ependymoma (grade II) and anaplastic ependymoma (grade III) (Kozler et al. 2007; Louis et al. 2007).

Immunohistochemical diagnosis relies on immunoreactivity to glial fibrillary acidic protein (GFAP), protein S-100 and to vimentin.

The only known hereditary form of ependymoma is part of neurofibromatosis type 2 (NF2). The NF2 gene is located on $22 \mathrm{q}$, which is often lost in ependymomas in spinal localization. However, most of these tumors in intracranial localization do not have alterations of this chromosome (Buccoliero et al. 2010). There have also been reported cases of ependymoma in patients with Li-Fraumeni syndrome, Turcot syndrome (Mullins et al. 1998) and multiple endocrine neoplasia type 1 syndrome (Al-Salameh et al. 2010). Furthermore, there are a few families with increased ependymoma incidence without any currently known familial cancer syndromes (Dimopoulos et al. 2006).

The most frequently observed chromosomal anomalies in pediatric ependymomas include loss of chromosomes $1 \mathrm{p}, 2$, $3,6 / 6 q, 9 p, 13 q, 17$, and 22 , as well as gains of $1 \mathrm{q}, 5,7,8,9$,
11, 18, and 20 (Kilday et al. 2009). In 50\% of ependymoma cases a deletion is present on chromosome 17 (Kozler et al. 2007). In adult ependymomas, chromosomes $6,10,13 q, 14 q$, 16 , and $22 / 22 \mathrm{q}$ are frequently lost whereas chromosomes 2,5 , $7,9,12,18$, and $\mathrm{X}$ are gained, with gains of 7 and 9 and loss of $22 \mathrm{q}$ being the most frequently observed, though with each occurring in only $30 \%$ of cases or less (Kilday et al. 2009).

The most frequently observed aberration in pediatric intracranial ependymomas is the gain of chromosome $1 \mathrm{q}$ (over 20\%). According to the literature, this genetic aberration is preferentially associated with tumors in the posterior fossa location and with anaplastic histological features. It is also a significant predictor of tumor aggressiveness and poor patient outcome (Kilday et al. 2009; Yao et al. 2011).

Homozygous deletion at CDKN2A locus is characteristic for anaplastic supratentorial tumors (Korshunov et al. 2010). This deletion is (together with young age at diagnosis and gain of 1q) one of the most reliable indicators of unfavorable outcome. In contrast, gains of chromosomes 9, 15q, and 18 and loss of chromosome 6 are features indicating excellent chance of survival. Deletion of CDKN2A occurrs in $>90 \%$ of supratentorial ependymomas but is rare in tumors from other parts of the CNS (Korshunov et al. 2010; Yao et al. 2011).

\section{Meningioma}

Meningiomas are thought to be formed from arachnoidal cap cells in the meningeal coverings (Louis et al. 2007). They are mostly benign, slowly growing tumors which represent 
up to $34 \%$ of primary brain tumors (CBTRUS 2008). According to WHO grading, there are 3 types of meningiomas: meningioma (grade I), atypical meningioma (grade II) and anaplastic meningioma (grade III), (Louis et al. 2007). Another classification is made according to their localization and histopathological features. Despite mostly being of histologically benign character they often invade brain tissue which explains a high amount of tumor recurrence. Risk factor for meningioma recurrence include histopathological malignancy grade, subtotal resection, young age, specific subtypes, brain infiltration and high proliferative rate (Torp et al. 2005; Backer-Grøndahl et al. 2012). Tumors with higher Ki-67 (proliferation index) and proliferating cell nuclear antigen (PCNA) are more likely to invade brain tissue independent of grade of the tumor. Recurrence rate after 5 years is $5 \%$ in grade I, $40 \%$ in grade II and $80 \%$ in grade III meningioma (Riemenschneider et al. 2006). Anaplastic (malignant) meningioma rarely metastases extracranialy (to lungs, liver and bones), it's just in $0.17 \%$ of cases (Choy et al. 2011).

Immunoreactivity for epithelial membranous antigen (EMA) - lower in atypical and anaplastic forms, for vimentin, for carcinoembryonic antigene (CEA) and for cytokeratin (both in secretory meningiomas) was observed in most of the meningiomas (Perry et al. 2004).

The most common genetic abnormality found in these tumors is monosomy 22 . About $50 \%$ of all meningiomas have loss of allele on $22 \mathrm{q}$, a region encoding the NF2 gene. Gene NF2 plays an important role in pathogenesis of autosomal dominant neurofibromatosis type 2 , in which meningiomas, schwannomas and other nervous system tumors are often present (Choy et al. 2011). Nearly all NF2associated tumors and $54-78 \%$ of sporadic meningiomas have deletions in this region (Ragel and Jensen 2005).

$D A L-1$ gene (differentially expressed in adenocarcinoma of the lung 1) is located at 18p11.3 and encodes protein $4.1 \mathrm{~B}$ - a regulator of proliferation and apoptosis (Choy et al. 2011). This protein has been implicated as a potential tumor suppressor in meningiomas (Gerber et al. 2006). LOH of $4.1 \mathrm{~B} / \mathrm{DAL}-1$ was reported in $60 \%$ of sporadic meningiomas (Gutmann et al. 2001), however, other studies showed a lower frequency (Nunes et al. 2005).

Telomerase is a reverse transcriptase that rebuilds the lost telomere repeat sequences and thus elongates chromosomes. Its activity is regulated during the development and growth of the human body (is found in fetal tissues, adult germ cells) and has a very low, almost undetectable activity in adult somatic cells (Choy et al. 2011). This enzyme is often reactivated in malignancies to sustain chromosomal integrity during aggressive growth. Its activity in grade I meningiomas is low (3-21\%). However, 58-92\% of atypical and $100 \%$ of anaplastic meningiomas demonstrate telomerase activity (Laurendeau et al. 2010). Telomerase activity is associated with higher recurrence rate and greater malignancy in meningiomas, and it may serve as a potential prognostic marker (Laurendeau et al. 2010; Choy et al. 2011).

Atypical and anaplastic tumors generally display more complex karyotypes associated with aggressive behavior (Yew et al. 2013). Atypical forms of meningioma have often deletions on chromosomes: 1p, 6q, 9q, 10q, 14q, 17p and 18q. The same alteration plus deletion on chromosomes $6 \mathrm{q}, 9 \mathrm{p}$, 10 and $14 \mathrm{q}$ are present in anaplastic forms. Deletions of $1 \mathrm{p}$ are the second most common chromosomal aberrations in higher grade meningiomas. It is also identified with a higher recurrence rate. Gene amplifications were identified in atypical and anaplastic meningiomas on chromosomes $1 \mathrm{q}, 9 \mathrm{q}$, 12q, 15q, 17q and 20q (Liu et al. 2005; Riemenschneider et al. 2006; Marwin and Perry 2010; Yew et al. 2013). Malignant progression is associated with a stepwise cumulative acquisition of chromosomal gains and losses (Choy et al. 2011; Yew et al. 2013). Increased CpG island hypermethylation, as an epigenetic alteration, has also been associated with malignant meningioma progression (Liu et al. 2005).

Various growth factors have been investigated in meningiomas. PDGF and its receptor PDGFR- $\beta$ are overexpressed in these tumors. Meningiomas also show overexpression of EGFR, which is not detectable in normal human meningeal tissue. EGFR ligands - TGF- $\alpha$ and EGF also contribute to the activation of EGFR (Perry et al. 2004; Choy et al. 2011). Increased expression of TGF- $\alpha$ is associated with more aggressive tumor growth. Meningiomas also express TGF- $\beta$ and its receptors (Wen et al. 2010).

VEGF and endotelin 1 (ET-1) play an important role in angiogenesis of meningiomas. VEGF-A and VEGFR-1 receptor have function in tumor neovascularisation and peritumoral edema. VEGF express 84\% and VEGFR 67\% of meningiomas (Ragel and Jensen 2010). It has been already proven that after total resection the secretion of VEGF-A from microscopic residues of tumor can cause neovascularisation and tumor recurrence (Yamasaki et al. 2000). Increased EGF and PDGF can induce VEGF expression (Ragel and Jensen 2010).

\section{Medulloblastoma}

Medulloblastoma is a malignant embryonic tumor with invasive growth. It appears in the cerebellum and is most often seen in children. It accounts for about $20 \%$ of all CNS tumors in children (Dhall 2009). At the time of diagnosis one-third of the patients have already present metastases in cerebrospinal fluid pathways.

The crucial factors for diagnosis of medulloblastoma are the immunohistochemical evidence of synaptophysin (marker of neuronal differentiation, not present in gliomas and mesenchymal tumors), intermediate filament proteins 
(IFP), mainly nestrin, vimentin and GFAP, neuron-specific IFP, retinal S-antigen, rhodopsin, NCAM (neural cell adhesion molecule - reflects the degree of differentiation), NGF (nerve growth factor) and its receptors Trk A, B and C (Takei et al. 2007). High values of proliferation index Ki-67 (over $20 \%$ ) are connected with a worse prognosis (Meurer et al. 2008). Expression of survivin correlates with poor clinical outcome and might be a predictive factor for the recurrence or presence of metastasis (Abdel-Aziz et al. 2013).

Gene-based research has already identified most common pathways connected with medulloblastoma: sonic hedgehog pathway (SHH), Wingless pathway (WNT) and NOTCH pathway (Northcott et al. 2011; Parsons et al 2011). Tight regulation of these cascades is essential for normal brain development. On the other hand, its dysregulation may cause tumorigenesis (Li et al. 2013). Recently, 4 molecular subgroups of medulloblastomas have been identified: $\mathrm{SHH}$, WNT, Group 3 and Group 4 (Robinson et al. 2012; Taylor et al. 2012; Li et al. 2013). Each of these subgroups has distinct molecular profiling and genomic defects, histological type, progenitors, clinical parameters, and patient outcomes (Gibson et al. 2010; Robinson et al. 2012).

SHH subgroup comprises about $25-30 \%$ of medulloblastomas with the high frequency of desmoplastic histology (Robinson et al. 2012; Li et al. 2013). The majority of SHH are found in infants under 3 years of age or in adults upwards of 16 years. Prognosis is good in infants and intermediate in adults. Regulators and target genes of $\mathrm{SHH}$ pathway (patched - PTCH, smoothened - SMO, suppressor of fused gene - SUFU, MYC, CCND1,CCND2 genes) are overexpressed in the $\mathrm{SHH}$ subgroup. The most frequent chromosomal abnormality in SHH is the loss of 9q (21-47\%), (Northcott et al. 2011; Pugh et al. 2012), followed by gain of 3q and 9p and loss of 10q, 20p and 21p (Northcott et al. 2012). Some tumors within this subgroup harbor amplifications and loss of genes associated also with p53 and PI3K pathway (Northcott et al. 2012; Li et al. 2013). These tumors also contain MLL2 (mixed lineage leukemia gene 2), MLL3, TP53 and PTEN mutations (Parsons et al. 2011).

WNT subgroup (10-15\% of all meduloblastomas) is characterized by classic histology (Kool et al. 2012), age above 3 years, good prognosis and infrequent metastasis ( $\mathrm{Li}$ et al. 2013). Genetic analyses have shown the enrichment of genes of WNT signaling pathway (adenomatous polyposis coli - APC, CTNN1, AXIN1, MYC, JUN, FRA, AXIN2, SMARCA4, CREBBP, MED13, CCND1 genes), CTNNB1 mutation, $D D X 3 X$ mutations and loss of chromosome 6 (Kool et al. 2012; Northcott et al. 2012; Pugh et al. 2012; Robinson et al. 2012; Min et al. 2013). Loss of chromosome 6 is associated with $88 \%$ of WNT tumors (Schwalbe et al. 2011).

Subgroup 3 and 4 display mostly classical histology, occur mostly in children and have poor (group 3) and intermediate (group 4) prognosis (Northcott et al. 2011; Li et al. 2013). Both subgroups have higher expression of genes involved in photoreceptor differentiation, high level of medulloblastoma oncogenes OTX2 and FOXG1B (Northcott et al. 2011; Robinson et al. 2012). Subgroup 3 shows alterations of genes involved in cell cycle, protein biosynthesis, glutamate receptor signaling and p38 mitogenactivated protein kinase (MMAPK) pathway, subgroup 4 has most often alterations of genes of neuronal differentiation and development, cytoskeleton organization and biogenesis and vesicle mediated transport (Northcott et al. 2011; Li et al. 2013). The most common structural abnormality is isochromosome 17q (I17q). I17q has breakpoint in proximal part of $17 \mathrm{p}$ resulting in dicentric chromosome with deletion on 17p. Higher incidence of I17q was observed in subgroup 4 (Northcott et al. 2011; Min et al. 2013). Other aberrations include gain of 7 and $18 \mathrm{q}$ and loss of 8 and $11 \mathrm{p}$. MYC and MYCN amplification, common in subgroup 3 (15\%), is very rarely observed in subgroup 4 (Kool et al. 2012; Robinson et al. 2012; Li et al. 2013).

Abnormalities of chromosome 1 (for example trisomy of 1q), loss of 10q, 11, trisomy of chromosome 7 are other possible genetic alterations. Hypermethylation of $\mathrm{HIC1}$ promotor was found in $80 \%$ of medulloblastoma cases (Waha et al. 2003).

\section{Malignant lymphoma}

Primary central nervous system lymphoma (PCNSL) is an uncommon extranodal non-Hodgkin lymphoma that accounts for $2.7 \%$ of all malignant brain tumors. It needs to be distinguished from secondary lymphomas that primarily grow in other localizations than in the central nervous system. Incidence of primary brain lymphoma has dramatically arisen in the last 3 decades. Known risk factors for development of PCNSL are AIDS (acquired immune deficiency syndrome), iatrogenic immune suppression for transplant procedures, congenital immune deficiency syndromes (e. g. ataxia-teleangiectasia, Wiskott-Aldrich syndrome) and autoimmune conditions (e. g. rheumatoid arthritis, systemic lupus erythematosus, myasthenia gravis etc.), (Bhagavathi and Wilson 2008).

Primary brain lymphomas are mostly composed of diffuse large B-cells (T-cell lymphomas and primary Hodgkin lymphomas are extremely rare) and in general have poorer prognosis than metastatic lymphomas. The immunohistochemical analyses show expression of CD45, CD20 ( $\beta$-cell marker found in large atypical cells), CD10, CD79a and CD3 (T-cell marker found in small benign admixed cells) markers, GFAP positivity, most of PCNSL also monoclonal superficial and cytoplasmic immunoglobulins (most often the combination $\operatorname{IgM} / \kappa)$. Most of these tumors are BCL2 
(B-cell lymphoma), BCL6 and MUM-1 positive (Camilleri-Broet et al. 2005; Lin et al. 2006). Interleukin-4 and STAT6 (signal transducer and activator of transcription) are involved in the pathogenesis of PCNSL; STAT6 is associated with tumor progression and a shortened survival (Rubenstein et al. 2006). Deletions are very often found on $6 \mathrm{q}$ (cca $50 \%), 6 \mathrm{p}, 17 \mathrm{p}$ and $18 \mathrm{p}$, amplifications on chromosome 1q, $7 \mathrm{q}, 12$ and 18q. Translocations have been also found $(1 ; 14$, $6 ; 14,13 ; 18$ and 14;21). Homozygous deletion and promoter hypermethylation of $C D K N 2 A$ is frequent (Bhagavathi and Wilson 2008), mutations of TP53 are extremely rare (Rubenstein et al. 2006).

Some cytokines and chemokines act as growth factors for tumor cells, inhibitors of apoptosis, attractors of immune cells, facilitators of invasion, promoters of angiogenesis and tumor-stromal cells interactions mediators (Sasayama et al. 2012).

Interleukin-10 (IL-10), produced by Th2-cells, monocytes and macrophages is known as growth and differentiation factor for B-cells and induces higher secretion of immunoglobulins (Mosser and Zhang 2008). IL-10 increases BCL2 expression and protects malignant cells for apoptosis. Elevated level of IL-10 in cerebro-spinal fluid is highly associated with the occurrence of PCNSL, shorter progression-free survival and overall survival (Sasayama et al. 2012).

CXCL12 and CXCL13 are known as homing factors for B-cells, production of CXCL13 in CNS is higher in patients with PCNSL and decreases with response to therapy (Fischer et al. 2009).

The favourable prognostic factors include a single, wellcircumscribed intracranial lesion, the absence of meningeal or periventricular tumor, the absence of immunodeficiency, and age younger than 60 years (Bhagavathi and Wilson 2008).

\section{Most common prognostic factors connected with brain tumors}

When interpreting molecular biological and other factors, it is necessary to distinguish whether the factor is etiological or prognostic. Molecular markers influencing the prognosis are shown in Table 2.

Astrocytic tumors exhibit various genetic alterations. Mutation of TP53 is very common in astrocytomas and is most important in the formation of astrocytomas grade II (Hede et al. 2011; Wang et al. 2011). It is also connected with their progression to secondary glioblastoma (Ohgaki and Kleihues 2007; Furnari et al. 2007). p53 was shown to be a prognostic marker (Levidou et al. 2010). Homozygous deletion (but not polymorphisms) in CDKN2A and loss of expression has been linked to poor prognosis in patients (Simon et al. 2010; Goldhoff et al. 2012).

Alterations of the $R B$ pathway play a critical role in gliomagenesis, tumor progression from lower-grade astrocytomas (Chow et al. 2011), has been associated with increased tumor proliferation and decreased survival (Kim et al. 2011). RB1 has a more direct correlation with prognosis in lower-grade (II, III) astrocytomas than glioblastoma (Kim et al. 2011).

PTEN is mutated or lost in $60-70 \%$ of high-grade glioma (Dey et al. 2008) and is associated with poor prognosis (Walker et al. 2011).

Progression from low-grade to anaplastic astrocytoma and formation of secondary glioblastoma is connected with a deletion on chromosomes $6,9 p, 11 p, 17 p, 13 q$, rarely with an amplification of 12q (Walker et al. 2011), decreased expression of DCC (Jarjour et al. 2011), mutation of TP53 (Ohgaki and Kleihues 2007; Furnari et al. 2007), amplification of EGFR (Hu et al. 2013), increased expression of Tie-2 receptor by endothelial cell (Fagiani and Christofori 2013)

Table 2. Molecular markers modifying survival in primary brain tumors

\begin{tabular}{|c|c|c|}
\hline Tumor type & Better survival & Shortened survival \\
\hline Astrocytoma & p27 expression, DCC expression & $\begin{array}{l}\text { VEGF, Tie- } 2 \text { receptor, CDKN2A deletion, RB pathway alterations, } 6,9 p \text {, } \\
11 p, 17 p, 13 q \text { deletions }\end{array}$ \\
\hline Glioblastoma & IDH mutations & $\begin{array}{l}\text { EGFR, PTEN mutation, Ki-67, expression of cathepsin B, Angiopoietin } \\
4 \text {, p53 dysfunction }\end{array}$ \\
\hline Oligodendroglioma & loss of chromosome $1 \mathrm{p}$ and $19 \mathrm{q}$ & CDKN2A, CDKN2C deletions, p53 dysfunction, 9,10 deletions \\
\hline Oligoastrocytoma & - & EGFR \\
\hline Ependymoma & $9,15 q, 18$ gain, 6 deletion & 1q gain, CDKN2A deletion \\
\hline Meningioma & telomerase activity & $1 \mathrm{p}, 6 \mathrm{q}, 9 \mathrm{p}, 10$ and $14 \mathrm{q}$ deletions, TGF- $\alpha$ expression \\
\hline Medulloblastoma & TrkC mRNA, SHH, Wnt subgroup & subgroup 3, 4, Ki-67, survivin \\
\hline Lymphoma & - & STAT 6, higher IL-10 in CSF \\
\hline
\end{tabular}

CDK, cyclin dependent kinase; CSF, cerebro-spinal fluid; DCC, deleted in colorectal cancer gene; EGFR, epidermal growth factor receptor; IDH, isocitrate dehydrogenase genes; PTEN, phosphatase and tensin homology; RB, retinoblastoma gene; SHH, sonic hedgehog pathway; STAT6, signal transducer and activator of transcription; VEGF, vascular endothelial growth factor receptor; Wnt, Wingless pathway. 
and increased expression of angiopoietin 4 (Brunckhorst et al. 2010), and others.

Mutations in the EGFR gene are associated with early relapses and poor prognosis ( $\mathrm{Hu}$ et al. 2013). Expression of EGFR is higher in high-grade and poorly-differentiated gliomas and together with amplification of EGFR is correlated with tumor progression (Hoelzinger et al. 2005; De Luca et al. 2008; Hofer and Lassman 2010; Hu et al. 2013).

Within the group of primary glioblastomas, IDH1 mutations are rare and create a prognostically favorable subgroup (Weller et al. 2009).

MGMT promoter hypermethylation is associated with prolonged progression-free survival and overall survival in patients with glioblastoma treated with alkylating agents (Hegi et al. 2005; Herrlinger et al. 2006; Glas et al. 2009). Methylation status of the MGMT promoter is clinically the most relevant molecular parameter (Weller et al. 2009) and has been used as a biomarker to predict the sensitivity of gliomas to DNA alkylating chemotherapeutics (Von Deimling et al. 2011).

Within the group of oligodendrogliomas, tumors with a combined loss of $1 \mathrm{p}$ and $19 \mathrm{q}$ create a group of good prognosis tumors (Giannini et al. 2008; Velnar et al. 2009), in patients treated with radiotherapy plus chemotherapy, also when treated with radiotherapy only (Cairncross et al. 2006; Van den Bent et al. 2006; Kouwenhoven et al. 2009; Weller et al. 2009).

Deletions on chromosomes 9 and 10 accompany malignant progression to anaplastic oligodendrogliomas (Stupp and Hegi 2007).

A CDKN2C deletion is present in anaplastic or mixed oligoastrocytomas. Tumors with such a deletion express poor chemosensitivity (Ducray et al. 2008). Patients with TP53 mutations (and intact 1p 19q chromosomes) have low efficacy rate of the chemotherapy treatment, thus having the worse prognosis. On the other hand, $100 \%$ response rate was observed in patients with $1 \mathrm{p} \mathrm{19q}$ codeletion and intact TP53 (Mueller et al. 2002).

Amplification of EGFR is more frequent in oligoastrocytomas and is connected with the worse overal survival (Kouwenhoven et al. 2009).

The most frequently observed aberration in pediatric intracranial ependymomas is the gain of chromosome $1 \mathrm{q}$ (over 20\%), what is a significant predictor of tumor aggressiveness and poor patient outcome (Kilday et al. 2009; Yao et al. 2011).

In ependymomas, homozygous deletion at CDKN2A is a predictor of unfavorable outcome (Korshunov et al. 2010). In contrast, gains of chromosomes $9,15 \mathrm{q}$, and 18 and loss of chromosome 6 are features indicating excellent chance of survival.

Telomerase activity in meningioma is associated with a higher recurrence rate and greater malignancy, and it may serve as a potential prognostic marker (Laurendeau et al. 2010; Choy et al. 2011).

Deletions of $1 \mathrm{p}$ are very common in higher grade meningiomas and it is also identified with a higher recurrence rate. Gene amplifications were identified in atypical and anaplastic meningiomas on chromosomes 1q, 9q, 12q, $15 \mathrm{q}, 17 \mathrm{q}$ and $20 \mathrm{q}$ (Liu et al. 2005; Riemenschneider et al. 2006; Marwin and Perry 2010; Yew et al. 2013). Increased $\mathrm{CpG}$ island hypermethylation, as an epigenetic alteration, has also been associated with malignant meningioma progression (Liu et al. 2005). Increased expression of TGF- $\alpha$ is associated with more aggressive tumor growth (Yew et al. 2013).

In medulloblastomas, high values (over 20\%) of expression of Ki-67 (factor of cell proliferation, which reflects degree of malignancy) are connected with a worse prognosis (Meurer et al. 2008). Expression of survivin correlates with poor clinical outcome and might be a predictive factor for recurrence or presence of metastasis (Abdel-Aziz et al. 2013).

Within the group of lymphomas, STAT6 is associated with tumor progression and a shortened survival (Rubenstein et al. 2006). An elevated level of IL-10 in cerebro-spinal fluid (CSF) is highly associated with the occurrence of PCNSL, shorter progression-free survival and overall survival (Sasayama et al. 2012). Production of CXCL13 in CNS is higher in patients with PCNSL and decreases with response to therapy (Fischer et al. 2009).

The favourable prognostic factors for lymphoma include a single, well-circumscribed intracranial lesion, the absence of meningeal or periventricular tumor, the absence of immunodeficiency, and age younger than 60 years (Bhagavathi and Wilson 2008).

Established prognostic factors for brain tumors, like age at the time of diagnosis, pathological grading, extend of surgery and Karnofsky performance score insufficiently predict the outcome in most instances. That is the reason why there is a need for more precise prognostic factors.

\section{Conclusion}

Recently there has been much progress in brain tumor research, although therapy remains limited. A lot of numerous chromosomal, genetic and epigenetic aberrations occur at random frequency in gliomas. However, the clinical value of most glioma-associated molecular aberrations in terms of their significance as diagnostic, prognostic or predictive molecular markers has remained unclear (Weller et al. 2009).

Morphologically indistinguishable tumors can be differentiated into molecular subtypes that might be eventually be used for identifying potential therapy targets and for determining prognosis. 
Effectiveness of brain tumor therapy is limited by the poor ability of therapy agents to cross the blood-brain barrier (Dai et al. 2003). Identification of molecular characteristics of brain tumor gives opportunity for the targeted molecular therapy, for example EGFR inhibitors, PDGFR inhibitors, farnesyltransferase inhibitor, mammalian target of rapamycin, VEGFR inhibitors and other inhibitors of angiogenesis (Wen and Kesari 2004). Other forms of promising therapeutic methods are gene therapy and immunotherapy. These approaches remain at an early stage of development. Ultimately, truly effective therapies will result from the use of combination of treatment modalities.

Tumors with the same histological appearance often display variable clinical behavior. Recently, molecular subgroups with various prognosis and therapy response have been identified. This is the reason why it is imperative to probe deeper into the molecular genetic basis in search of reliable prognostic markers and therapeutic targets. A better understanding of the brain tumor biology is necessary in order to reveal ways of improving therapy and prolong sufficient life quality of patients with brain tumors.

\section{References}

Abdel-Aziz A., Mohamed M. A., Akl F. M., Taha A. N. (2013): Survivin expression in medulloblastoma: a possible marker for survival. Pathol. Oncol. Res. 19, 413-419 http://dx.doi.org/10.1007/s12253-012-9594-9

Al-Salameh A., Francois P., Giraud S., Calender A., BergemerFouquet A. M., de Calan L., Goudet P., Lecomte P. (2010): Intracranial ependymoma associated with multiple endocrine neoplasia type 1. J. Endocrinol. Invest. 33, 353-356 http://dx.doi.org/10.1007/BF03346599

Albesiano E., Han J. E., Lim M. (2010): Mechanisms of local immunoresistance in glioma. Neurosurg. Clin. N. Am. 21, 17-29 http://dx.doi.org/10.1016/j.nec.2009.08.008

Backer-Grøndahl T., Moen B. H., Torp S. H. (2012): The histopathological spectrum of human meningiomas. Int. J. Clin. Exp. Pathol. 5, 231-242

Balss J., Meyer J., Mueller W., Korshunov A., Hartmann C., von Deimling A. (2008): Analysis of the IDH1 codon 132 mutation in brain tumors. Acta Neuropathol. 116, 597-602 http://dx.doi.org/10.1007/s00401-008-0455-2

Bhagavathi S., Wilson J. D. (2008): Primary central nervous system lymphoma. Arch. Pathol. Lab. Med. 132, 1830-1834

Bhowmick D. A., Zhuang Z., Wait S. D., Weil R. J. (2004): A functional polymorphisms in the EGF gene is found with increased frequency in glioblastoma multiforme patients and is associated with more aggressive disease. Cancer Res. 64, 1220-1223 http://dx.doi.org/10.1158/0008-5472.CAN-03-3137

Bleeker F. E., Lamba S., Zanon C., van Tilborg A. A., Leenstra S., Troost D., Hulsebos T., Vandertop W. P., Bardelli A. (2009): Absence of AKT1 mutations in glioblastoma. PLoS One 4, e5638 http://dx.doi.org/10.1371/journal.pone.0005638
Bondy M. L., Scheurer M. E., Malmer B., Barnholtz-Sloan J. S., Davis F. G., Il'yasova D., Kruchko C., McCarthy B. J., Rajaraman P., Schwartzbaum J. A., Sadetzki S., Schlehofer B., Tihan T., Wiemels J. L, Wrensch M., Buffler P. A. (2008): Brain tumor epidemiology: Consensus from the Brain Tumor Epidemiology Consortium (BTEC). Cancer 113, 1953-1968 http://dx.doi.org/10.1002/cncr.23741

Brown P. D., Krishnan S., Sarkaria J. N., Wu W., Jaeckle K. A., Uhm J. H., Geoffroy F. J., Arusell R., Kitange G., Jenkins R. B., et al. (2008): North Central Cancer Treatment Group Study N0177: Phase I/II trial of erlotinib and temozolomide with radiation therapy in the treatment of newly diagnosed glioblastoma multiforme: North Central Cancer Treatment Group Study N0177. J. Clin. Oncol. 26, 5603-5609 http://dx.doi.org/10.1200/JCO.2008.18.0612

Brunckhorst M. K., Wang H., Lu R., Yu Q. (2010): Angiopoietin-4 promotes glioblastoma progression by enhancing tumor cell viability and angiogenesis. Cancer Res. 70, 7283-7293 http://dx.doi.org/10.1158/0008-5472.CAN-09-4125

Buccoliero A. M., Castiglione F., Degl'Innocenti D. R., Sardi I., Genitori L., Taddei G. L. (2010): Merlin expression in pediatric anaplastic ependymomas real time PCR study. J. Fetal Pediatr. Pathol. 29, 245-254 http://dx.doi.org/10.3109/15513811003789644

Cairncross J. G., Berkey B., Shaw E., Jenkins R., Scheithauer B., Brachman D., Buckner J., Fink K., Souhami L., Laperierre N., Mehta M., Curran W. (2006): Phase III trial of chemotherapy plus radiotherapy compared with radiotherapy alone for pure and mixed anaplastic oligodendroglioma: Intergroup Radiation Therapy Oncology Group Trial 9402. J. Clin. Oncol. 24, 2707-2714 http://dx.doi.org/10.1200/JCO.2005.04.3414

Camilleri-Broët S., Criniére E., Broët P., Delwail V., Mokhtari K., Moreau A., Kujas M., Raphaël M., Iraqi W., Sautés-Fridman C., Colombat P., Hoang-Xuan K., Martin A. (2005): A uniform activated B-cell-like immunophenotype might explain the poor prognosis of primary central nervous system lymphomas: analysis of 83 cases. Blood 107, 190-196 http://dx.doi.org/10.1182/blood-2005-03-1024

Charles N. A., Holland E. C., Gilbertson R., Glass R., Kettenmann H. (2011): The brain tumor microenvironment. Glia 59, $1169-1180$ http://dx.doi.org/10.1002/glia.21136

CBTRUS: statistical report: primary brain tumors in the United States, 2000-2004. Hinsdale, IL, Central Brain Tumor Registry of the United States. (2008)

Choy W., Kim W., Nagasava D., Stramotas S., Yew A., Gopen Q., Parsa A. T., Yang I. (2011): The molecular genetics and tumor pathogenesis of meningiomas and the future directions of meningioma treatments. Neurosurg. Focus 30, 1-12

Chow L. M., Endersby R., Zhu X., Rankin S., Qu C., Zhang J., Broniscer A., Ellison D. W., Baker S. J. (2011): Cooperativity within and among Pten, $\mathrm{p} 53$, and $\mathrm{Rb}$ pathways induces high-grade astrocytoma in adult brain. Cancer Cell 19, 305-316 http://dx.doi.org/10.1016/j.ccr.2011.01.039

Costa B. M., Ferreira P., Costa S., Canedo P., Oliveira P., Silva A., Pardal F., Suriano G., Machado J. C., Lopes J. M., Reis R. M. (2007): Association between functional EGF +61 polymorphism and glioma risk. Clin. Cancer Res. 13, 2621-2626 
http://dx.doi.org/10.1158/1078-0432.CCR-06-2606

Curran C. S., Bertics P. J. (2012): Eosinophils in glioblastoma biology. J. Neuroinflamation 9, 11-25 http://dx.doi.org/10.1186/1742-2094-9-11

Dai H., Marbach P., Lemaire M., Hayes M., Elmquist W. F. (2003): Distribution of STI-571 to the brain is limited by Pglycoprotein-mediated efflux. J. Pharmacol. Exp. Ther. 304, 1085-1092 http://dx.doi.org/10.1124/jpet.102.045260

De Luca A., Carotenuto A., Rachiglio A., Gallo M., Maiello M. R., Aldinucci D., Pinto A., Normanno N. (2008): The role of the EGFR signaling in tumor microenvironment. J. Cell. Physiol. 214, 559-567 http://dx.doi.org/10.1002/jcp.21260

Dey N., Crosswell H. E., De P., Parsons R., Peng Q., Su J. D., Durden D. L.(2008): The Protein Phosphatase Activity of PTEN Regulates Src Family Kinases and Controls Glioma Migration. Cancer Res. 68, 1862-1871 http://dx.doi.org/10.1158/0008-5472.CAN-07-1182

Dhall G. (2009): Medulloblastoma. J. Child. Neurol. 24, 14181430 http://dx.doi.org/10.1177/0883073809341668

Dimopoulos V. G., Fountas K. N., Robinson J. S. (2006): Familial intracranial ependymomas. Report of three cases in a family and review of the literature. Neurosurg Focus 20, E8 http://dx.doi.org/10.3171/foc.2006.20.1.9

Ducray F., Idbaih A., de Reyniés A., Biéche I., Thillet J., Mokhtari K., Lair S., Marie Y., Paris S., Vidaud M., Hoang-Xuan K., Delattre J. Y., Sanson M. (2008): Anaplastic oligodendrogliomas with $1 \mathrm{p} 19 \mathrm{q}$ codeletion have a proneural gene expression profile. Mol. Cancer. 7, 41 http://dx.doi.org/10.1186/1476-4598-7-41

Eischen C. M., Lozano G. (2009): p53 and MDM2: antagonists or partners in crime? Cancer Cell 15, 161-162 http://dx.doi.org/10.1016/j.ccr.2009.02.004

Engelhard H. H., Stelea A., Mundt A. (2003): Oligodendroglioma and anaplastic oligodendroglioma: clinical features, treatment, and prognosis. Surg. Neurol. 60, 443-456 http://dx.doi.org/10.1016/S0090-3019(03)00167-8

Fagiani E., Christofori G. (2013): Angiopoietins in angiogenesis. Cancer letters 328, 18-26 http://dx.doi.org/10.1016/j.canlet.2012.08.018

Fisher J. L., Schwartzbaum J. A., Wrensch, M., Wiemels, J. L. (2007): Epidemiology of brain tumors. Neurol. Clin. 25, 867-890 http://dx.doi.org/10.1016/j.ncl.2007.07.002

Fischer L., Korfel A., Pfeiffer S., Kiewe P., Volk H. D., Cakiroglu H., Widmann T., Thiel E. (2009): CXCL13 and CXCL12 in central nervous system lymphoma patients. Clin. Cancer Res. 15, 5968-5973 http://dx.doi.org/10.1158/1078-0432.CCR-09-0108

Fulda S. (2010): Evasion of apoptosis as a cellular stress response in cancer. Int. J. Cell Biol. 2010

Furnari F. B., Fenton T., Bachoo R. M., Mukasa A., Stommel J. M., Stegh A., Hahn W. C., Ligon K. L., Louis D. N., Brennan C., Chin L., DePinho R. A., Cavenee W. K. (2007): Malignant astrocytic glioma: genetics, biology, and paths to treatment. Genes Dev. 21, 2683-2710 http://dx.doi.org/10.1101/gad.1596707
Furstenberger G., Senn H. J. (2002): Insulin.like growth factors and cancer. Lancet Oncol. 3, 298-302 http://dx.doi.org/10.1016/S1470-2045(02)00731-3

Gerber M. A., Bahr S. M., Gutmann D. H. (2006): Protein 4.1B/differentially expressed in adenocarcinoma of the lung- 1 function as a growth suppressor in meningioma cells by activating Rac1-dependent c-Jun-NH(2)-kinase signaling. Cancer Res. 66, 5295-5303 http://dx.doi.org/10.1158/0008-5472.CAN-05-1628

Giannini C., Burger P. C., Berkey B. A, Cairncross J. G., Jenkins R. B., Mehta M., Curran W. J., Aldape K. (2008): Anaplastic oligodendroglial tumors: refining the correlation among histopathology, 1p 19q deletion and clinical outcome in Intergroup Radiation Therapy Oncology Group Trial 9402. Brain Pathol. 18, 360-369 http://dx.doi.org/10.1111/j.1750-3639.2008.00129.x

Gibson P., Tong Y., Robinson G., Thompson M. C., Currle D. S., Eden C., Kranenburg T. A., Hogg T., Poppleton H., Martin J., et al. (2010): Subtypes of medulloblastoma have distinct developmental origins. Nature 468, 1095-1099 http://dx.doi.org/10.1038/nature09587

Gil-Gil M. J., Mesia C., Rey M., Bruna J. (2013): Bevacizumab for the treatment of glioblastoma. Clin. Med. Insights Oncol. 6, 123-135 http://dx.doi.org/10.4137/CMO.S8503

Glas M., Happold C., Rieger J., Wiewrodt D., Bähr O., Steinbach J. P., Wick W., Kortmann R. D., Reifenberger G., Weller M., Herrlinger U. (2009): Long-term survival of glioblastoma patients treated with radiotherapy and lomustine plus temozolomide. J. Clin. Oncol. 27, 1257-1261 http://dx.doi.org/10.1200/JCO.2008.19.2195

Goldhoff P., Clarke J., Smirnov I., Berger M. S., Prados M. D., James C. D., Perry A., Phillips J. J. (2012): Clinical stratification of glioblastoma based on alterations in retinoblastoma tumor suppressor protein (RB1) and association with the proneural subtype. J. Neuropathol. Exp. Neurol. 71, 83-89 http://dx.doi.org/10.1097/NEN.0b013e31823fe8f1

Gutmann D. H., Hirbe A. C., Huang Z. Y., Haipek C. A. (2001): The protein 4.1 tumor suppressor, DAL-1, impairs cell motility, but regulates proliferation in a cell-type-specific fashion. Neurobiol. Dis. 8, 266-278 http://dx.doi.org/10.1006/nbdi.2000.0376

He G., Kuang J., Huang Z., Koomen J., Kobayashi R., Khokhar A. R., Siddik Z. H. (2006): Upregulation of p27 and its inhibition of CDK2/cyclin E activity following DNA damage by a novel platinum agent are dependent on the expression of p21. Br. J. Cancer 95, 1514-1524 http://dx.doi.org/10.1038/sj.bjc.6603448

Hede S. M., Nazarenko I., Nistér M., Lindström M. S. (2011): Novel Perspectives on p53 Function in Neural Stem Cells and Brain Tumors. J. Oncol. 2011, 852970 http://dx.doi.org/10.1155/2011/852970

Hegi M. E., Diserens A. C., Corlia T., Hamou M. F., Tribolet N., Weller M., Kros J. M., Hainfeller J. A., Mason W., Mariani L., Bromberg J. E. C., Hau P., Mirimanoff R. O., Cairncross G., Janzer R. C., Stupp, R. (2005): MGMT gene silencing and benefit from temozolomide in glioblastoma. N. Engl. J. Med. 352, 997-1003 
http://dx.doi.org/10.1056/NEJMoa043331

Herrlinger U., Rieger J., Koch D., Kortmann R., Hundsberger T., Schuth J., Bamberg M., Weller M. (2006): Phase I/II trial (UKT03) of CCNU plus temozolomide chemotherapy in addition to radiotherapy as first-line therapy for glioblastoma. J. Clin. Oncol. 24, 4412-4417 http://dx.doi.org/10.1200/JCO.2006.06.9104

Hoelzinger D. B., Mariani L., Weis J., Woyke T., Berens T. J., McDonough W. S., Sloan A., Coons S. W., Berens M. E. (2005): Gene expression profile of glioblastoma multiforme invasive phenotype points to new therapeutic targets. Neoplasia 7, $7-16$ http://dx.doi.org/10.1593/neo.04535

Hofer S., Lassman A. B. (2010): Molecular markers in gliomas: impact for the clinician. Target Oncol. 3, 201-210 http://dx.doi.org/10.1007/s11523-010-0157-2

Hu X., Miao W., Zou Y., Zhang W., Zhang Y., Liu H. (2013): Expression of p53, epidermal growth factor receptor, Ki-67 and O6-methylguanine-DNA methyltransferase in human gliomas. Oncol. Lett. 6, 130-134

Iacob G., Dinca E. B. (2009): Current data and strategy in glioblastoma multiforme. J. Med. Life 2, 386-393

Ichimura K., Pearson D. M., Kocialkowski S., Bäcklund L. M., Chan R., Jones D. T., Collins V. P. (2009): IDH1 mutations are present in the majority of common adult gliomas but rare in primary glioblastomas. Neuro Oncol. 11, 341-347 http://dx.doi.org/10.1215/15228517-2009-025

Jarjour A. A., Durko M., Luk T. L., Marçal N., Shekarabi M., Kennedy T. E. (2011): Autocrine netrin function inhibits glioma cell motility and promotes focal adhesion formation. PLoS One 6, e25408 http://dx.doi.org/10.1371/journal.pone.0025408

Jha P., Suri V., Sharma V., Singh G., Sharma M. C., Pathak P., Chosdol K., Jha P., Suri A., Mahapatra A. K., Kale S. S., Sarkar C. (2011): IDH mutations in gliomas: first series from a tertiary care centre in India with comprehensive review of literature. Exp. Mol. Pathol. 91, 385-393

http://dx.doi.org/10.1016/j.yexmp.2011.04.017

Jiang X., Yu Y., Yang H. W., Agar N. Y., Frado L., Johnson M. D. (2010): The imprinted gene PEG3 inhibits Wnt signaling and regulates glioma growth. J. Biol. Chem. 285, 8472-8480 http://dx.doi.org/10.1074/jbc.M109.069450

Kilburn L., Okcu F., Wang T., Cao Y., Renfro-Spelman A., Aldape K. D., Gilbert M. R., Bondy,M. (2010): Glutathione S-Transferase polymorphism are associated with survival in anaplastic glioma patients. Cancer 116, 2242-2249

Kilday J. P., Rahman, R., Dyer S., Ridley L., Lowe J., Coyle B., Grundy R. (2009): Pediatric Ependymoma: Biological Perspectives. Mol. Cancer Res. 7, 765-786 http://dx.doi.org/10.1158/1541-7786.MCR-08-0584

Kim C. S., Jung S., Jung T. Y., Jang W. Y., Sun H. S., Ryu H. H. (2011): Characterization of invading glioma cells using molecular analysis of leading-edge tissue. J. Korean Neurosurg. Soc. 50, 157-165 http://dx.doi.org/10.3340/jkns.2011.50.3.157

Kim W., Liau L. M. (2012): IDH mutations in human glioma. Neurosurg. Clin. N. Am. 23, 471-480 http://dx.doi.org/10.1016/j.nec.2012.04.009
Kim Y. H., Lachuer J., Mittelbronn M., Paulus W., Brokinkel B., Keyvani K., Sure U., Wrede K., Nobusawa S., Nakazato Y., Tanaka Y., Vital A., Mariani L, Ohgaki H. (2011): Alterations in the RB1 pathway in low-grade diffuse gliomas lacking common genetic alterations. Brain Pathol. 21, 645-651 http://dx.doi.org/10.1111/j.1750-3639.2011.00492.x

Knizhnik A. V., Roos W. P., Nikolova T., Quiros S., Tomaszowski K.-H., Christmann M., Kaina B. (2013): Survival and death strategies in glioma cells: autophagy, senescence and apoptosis triggered by a single type of temozolomide-induced DNA damage. PLoS One 8, e55665 http://dx.doi.org/10.1371/journal.pone.0055665

Kool M., Korshunov A., Remke M., Jones D. T., Schlanstein M., Northcott P. A., Cho Y. J., Koster J., Schouten-van Meeteren A., van Vuurden D., et al. (2012): Molecular subgroups of medulloblastoma: an international meta-analysis of transcriptome, genetic aberrations, and clinical data of WNT, SHH, Group 3, and Group 4 medulloblastomas. Acta Neuropathol. 123, 473-484 http://dx.doi.org/10.1007/s00401-012-0958-8

Korshunov A., Witt H., Hielscher T., Benner A., Remke M., Ryzhova M., Milde T., Bender S., Wittmann A., Schöttler A., Kulozik A. E., Witt O., von Deimling A., Lichter P., Pfister S. (2010): Molecular staging of intracranial ependymoma in children and adults. J. Clin. Oncol. 28, 3182-3190

http://dx.doi.org/10.1200/JCO.2009.27.3359

Kouwenhoven M. C.M., Gorlia T., Kros J. M., Ibdaih A., Brandes A. A., Bromberg J. E. C., Mokhtari K., van Duinen S. G., Teepen J. L., Wesseling P., Vandenbos F., Grisold W., Sipos L., Mirimanoff R., Vecht C. J., Allgeier A., Lacombe D., van den Bent M. J. (2009): Molecular analysis of anaplastic oligodendroglial tumors in a prospective randomized study: A report from EORTC study 26951. Neuro Oncol. 11, 737-746 http://dx.doi.org/10.1215/15228517-2009-011

Kozler P., Beneš V., Chytka T., Kramář F. (2007): Intracranial Tumors (Intrakranialní nádory). Galén, Prague (in Czech)

Krakstad C., Chekenya M. (2010): Survival signalling and apoptosis resistance in glioblastomas: opportunities for targeted therapeutics. Mol. Cancer 9, 135-149 http://dx.doi.org/10.1186/1476-4598-9-135

Lal A., Glazer C. A., Martinson H. M., Friedman H. S., Archer G. E., Sampson J. H., Riggins G. J. (2002): Mutant epidermal growth factor receptor up-regulates molecular effectors of tumor invasion. Cancer Res. 62, 3335-3339

Laurendeau I., Ferrer M., Garrido D., D’Haene N., Ciavarelli P., Basso A., Vidaud M., Bieche I., Salmon I., Szijan I. (2010): Gene expression profiling of the hedgehog signaling pathway in human meningiomas. Mol. Med. 16, 262-270 http://dx.doi.org/10.2119/molmed.2010.00005

Lee J. J., Kim B. C., Park M. J., Lee Y. S, Kim Y. N., Lee B. L. Lee J. S. (2011): PTEN status switches cell fate between premature senescence and apoptosis in glioma exposed to ionizing radiation. Cell Death Differ. 18, 666-677 http://dx.doi.org/10.1038/cdd.2010.139

Levidou G., El-Habr E., Saetta A. A., Bamias C., Katsouyanni K., Patsouris E., Korkolopoulou P. (2010): P53 immunoexpression as a prognostic marker for human astrocytomas: a meta-analysis and review of the literature. J. Neurooncol. 100, 363-371 
http://dx.doi.org/10.1007/s11060-010-0204-y

Li Calzi S., Neu M. B., Shaw L. C., Kielczewski J. L., Moldovan N. I., Grant M. B. (2010): EPCs and pathological angiogenesis: when good cells go bad. Microvasc. Res. 79, 207-216 http://dx.doi.org/10.1016/j.mvr.2010.02.011

Li K. K., Lau K. M., Ng H. K. (2013): Signaling pathway and molecular subgroups of medulloblastoma. Int. J. Clin. Exp. Pathol. 6, 1211-1222

Lin C. H., Kuo K. T. Chuang S. S., Kuo S. H., Chang J. H., Chang K. C., Hsu H. C., Tien H. F., Cheng A. L. (2006): Comparison of the expression and prognostic significance of differentiation markers between diffuse large B-cell lymphoma of central nervous origin and peripheral nodal origin. Clin.Cancer Res. 12, 1152-1156 http://dx.doi.org/10.1158/1078-0432.CCR-05-1699

Liu Y., Pang J. C., Dong S., Mao B., Poon W. S., Ng H. K. (2005): Aberrant $\mathrm{CpG}$ island hypermethylation profile is associated with atypical and anaplastic meningiomas. Hum. Pathol. 36, $416-425$ http://dx.doi.org/10.1016/j.humpath.2005.02.006

Liu Y., Shete S., Hosking F. J., Robertson L. B., Bondy M. L., Houlston R. S. (2010): New insights into susceptibility to glioma. Arch. Neurol. 67, 275-278 http://dx.doi.org/10.1001/archneurol.2010.4

Lo H., Ali-Osman, F. (2007): Genetic polymorphism and function of glutatione S-transferases In tumor drug resistance. Curr. Opin. Pharmacol. 7, 367-374 http://dx.doi.org/10.1016/j.coph.2007.06.009

Lockshin R. A., Zakeri Z. (2007): Cell death in health and disease. J. Cell. Mol. Med. 11, 1214-1224 http://dx.doi.org/10.1111/j.1582-4934.2007.00150.x

Lönn S., Rothman N., Shapiro W. R, Fine H. A., Selker R. G., Black P. M., Loeffler J. S., Hutchinson A. A., Inskip P. D. (2008): Genetic variation in insulin-like growth factors and brain tumor risk. Neuro-Oncol. 10, 553-559 http://dx.doi.org/10.1215/15228517-2008-026

Louis D. N., Ohgaki H., Wiestler O. D., Cavenee W. K., Burger P. C., Jouvet A., Scheithauer B. W., Kleihues P. (2007): The 2007 WHO classification of the tumours of the central nervous system. Acta Neuropathol. 2, 97-109 http://dx.doi.org/10.1007/s00401-007-0243-4

Malumbres M., Barbacid M. (2009): Cell cycle, CDKs and cancer: A changing paradigm. Nat. Rev. Cancer 9, 153-166 http://dx.doi.org/10.1038/nrc2602

Marwin C., Perry A. (2010): Pathological classification and molecular genetics of meningiomas. J. Neurooncol. 99, 379-391 http://dx.doi.org/10.1007/s11060-010-0342-2

Mellai M., Schiffer D. (2007): Apoptosis in brain tumors: prognostic and therapeutic considerations. Anticancer Research 27, 437-448

Meurer R. T., Martins D. T., Hilbig A., de Castro Ribeiro M., Roehe A. V., Barbosa-Coutinho L. M., da Cruz Fernandes M. (2008): Immunohistochemical expression of markers ki-67, neun, synaptophysin, P53 and HER2 in medulloblastoma and its correlation with clinicopathological parameters. Arq. Neuropsiquiatr. 66, 385-390 http://dx.doi.org/10.1590/S0004-282X2008000300020
Min H. S., Lee J. Y., Kim S. K., Park S. H. (2013): Genetic grouping of medulloblastomas by representative markers in pathologic diagnosis. Transl. Oncol. 6, 265-272 http://dx.doi.org/10.1593/tlo.12382

Mosser D. M., Zhang X. (2008): Interleukin-10: new perspectives on an old cytokine. Immunol. Rev. 226, 205-218 http://dx.doi.org/10.1111/j.1600-065X.2008.00706.x

Mueller W., Hartmann C., Hoffmann A., Lanksch W., Kiwit J., Tonn J., Veelken J., Schramm J., Weller M., Wiestler O. D., Louis D. N., von Deimling A. (2002): Genetic signature of oligoastrocytomas correlates with tumor location and denotes distinct molecular subsets. Am. J. Pathol. 161, 313-319 http://dx.doi.org/10.1016/S0002-9440(10)64183-1

Mullins K.J., Rubio A., Myers S. P., Korones D. N., Pilcher W. H. (1998): Malignant ependymomas in a patient with turcot's syndrome: case report and management guidelines. Surg. Neurol. 49, 290-294 http://dx.doi.org/10.1016/S0090-3019(97)00299-1

Mustafa D. A., Dekker L. J., Stingl C., Kremer A., Stoop M., Sillevis Smitt P. A., Kros J. M., Luider T. M. (2012): A proteome comparison between physiological angiogenesis and angiogenesis in glioblastoma. Mol. Cell. Proteomics 11, M111.008466

Narita Y., Nagane M., Mishima K., Huang H.-J. S., Furnari F. B., Cavenee W. K. (2002): Mutant epidermal growth factor receptor signalling down-regulates 27 through activation of the phosphatidylinositol 3-kinase/Akt pathway in glioblastomas. Cancer Res. 62, 6764-6769

Nigro J. M., Baker S. J., Preisinger A. C., Jessup J. M., Hosteller R., Cleary K., Signer S. H., Davidson N., Baylin S., Devilee P., Glover T., Collins F. S., Weslon A., Modali R., Harris C. C., Vogelstein B. (1989): Mutations in the p53 gene occur in diverse human tumour types. Nature 342, 705-708 http://dx.doi.org/10.1038/342705a0

Norden A. D., Young G. S., Setayesh K., Muzikansky A., Klufas R., Ross G. L., Ciampa A. S., Ebbeling L. G., Levy B., Drappatz J., Kesari S., Wen P. Y. (2008): Bevacizumab for recurrent malignant gliomas: efficacy, toxicity, and patterns of recurrence. Neurology 70, 779-787 http://dx.doi.org/10.1212/01.wnl.0000304121.57857.38

Northcott P. A., Korshunov A., Witt H., Hielscher T., Eberhart C. G., Mack S., Bouffet E., Clifford S. C., Hawkins C. E., French P., Rutka J. T., Pfister S., Taylor M. D. (2011): Medulloblastoma comprises four distinct molecular variants. J. Clin. Oncol. 29, 1408-1414 http://dx.doi.org/10.1200/JCO.2009.27.4324

Northcott P. A., Shih D. J., Peacock J., Garzia L., Morrissy A. S., Zichner T., Stütz A. M., Korshunov A., Reimand J., Schumacher S. E., et al. (2012): Subgroup-specific structural variation across 1,000 medulloblastoma genomes. Nature 488, 49-56 http://dx.doi.org/10.1038/nature11327

Nunes F., Shen Y., Niida Y., Beauchamp R., Stemmer-Rachamimov A. O., Ramesh V., Gusella J., MacCollin M. (2005): Inactivation patterns of NF2 and DAL-1/4.1B (EPB41L3) in sporadic meningioma. Cancer Genet. Cytogenet. 162, 135-139 http://dx.doi.org/10.1016/j.cancergencyto.2005.04.003

Nupponen N. N., Joensuu H. (2006): Molecular pathology of gliomas. Current Diagnostic Pathology 12, 394-402 http://dx.doi.org/10.1016/j.cdip.2006.06.007 
Ohgaki H., Kleihues P. (2007): Genetic pathways to primary and secondary glioblastoma. Am. J. Pathol. 170, 1445-1453 http://dx.doi.org/10.2353/ajpath.2007.070011

Ohgaki H. (2009): Epidemiology of brain tumors. Methods Mol. Biol. 472, 323-342 http://dx.doi.org/10.1007/978-1-60327-492-0_14

Okcu M. F., Selvan M., Wang L. E., Stout L., Erana R., Airwele G., Adatto P., Hess K., Ali-Osman F., Groves M., Yung A. W. K., Levin V. A., Wei Q., Bondy M. (2004): Glutathione S-transferase polymorphisms and survival in primary malignant glioma. Clin. Cancer Res. 10, 2618-2625 http://dx.doi.org/10.1158/1078-0432.CCR-03-0053

Otsuka S., Maegawa S., Takamura A., Kamitani H., Watanabe T., Oshimura M., Nanba, E. (2009): Aberrant promoter methylation and expression of the imprinted PEG3 gene in glioma. Proc. Jpn. Acad. Ser. B. 85, 157-165 http://dx.doi.org/10.2183/pjab.85.157

Parhar P., Ezer R., Shao Y., Allen J. C., Miller D. C., Newcomb E. W. (2005): Possible association of p53 codon 72 polymorphism with susceptibility to adult and pediatric high-grade astrocytomas. Mol. Brain Res. 137, 98-103 http://dx.doi.org/10.1016/j.molbrainres.2005.02.016

Parsons D. W., Jones S., Zhang X., Lin J. C., Leary R. J., Angenendt P., Mankoo P., Carter H., Siu I. M., Gallia G. L. et al. (2008): An integrated genomic analysis of human glioblastoma multiforme. Science 321, 1807-1812 http://dx.doi.org/10.1126/science.1164382

Parsons D. W., Li M., Zhang X., Jones S., Leary R. J., Lin J. C., Boca S. M., Carter H., Samayoa J., Bettegowda C., Gallia G. L. et al. (2011): The genetic landscape of the childhood cancer medulloblastoma. Science 331, 435-439 http://dx.doi.org/10.1126/science.1198056

Perry A., Gutmann D. H., Reifenberger G. (2004): Molecular pathogenesis of meningiomas. J. Neurooncol. 70, 183-202 http://dx.doi.org/10.1007/s11060-004-2749-0

Persson A. I., Petritsch C., Swartling F. J., Itsara M., Sim F. J., Auvergne R., Goldenberg D. D., Vandenberg S. R., Nguyen K. N., Yakovenko S. et al. (2010): Non-stem cell origin for oligodendroglioma. Cancer Cell 18, 669-682 http://dx.doi.org/10.1016/j.ccr.2010.10.033

Pinarbasi H., Silig Y., Gurelik M. (2005): Genetic polymorphisms of GSTs and their association with primary brain tumor incidence. Cancer Genet. Cytogenet. 156, 144-149 http://dx.doi.org/10.1016/j.cancergencyto.2004.04.020

Pugh T. J., Weeraratne S. D., Archer T. C., Pomeranz Krummel D. A., Auclair D., Bochicchio J., Carneiro M. O., Carter S. L., Cibulskis K., Erlich R. L. et al. (2012): Medulloblastoma exome sequencing uncovers subtype-specific somatic mutations. Nature 488, 106-110 http://dx.doi.org/10.1038/nature11329

Puputti M., Tynninen O., Sihto H., Blom T., Mäenpää H., Isola J., Paetau A., Joensuu H., Nupponen N. N. (2006): Amplification of KIT, PDGFRA, VEGFR2, and EGFR in Gliomas. Mol. Cancer Res. 4, 927-934 http://dx.doi.org/10.1158/1541-7786.MCR-06-0085

Pusch S., Sahm F., Meyer J., Mittelbronn M., Hartmann C., von Deimling A. (2011): Glioma IDH 1 mutation patterns off the beaten track. Neuropathol. Appl. Neurobiol. 37, 428-430 http://dx.doi.org/10.1111/j.1365-2990.2010.01127.x

Ragel B. T., Jensen R. L. (2005): Molecular genetics of meningiomas. Neurosurg. Focus 19, E9

http://dx.doi.org/10.3171/foc.2005.19.5.10

Ragel B. T., Jensen R. L. (2010): Aberrant signaling pathways in meningiomas. J. Neurooncol. 99, 315-324 http://dx.doi.org/10.1007/s11060-010-0381-8

Rajasekharan S., Kennedy T. E. (2009): The netrin protein family. Genome Biol. 10, 239 http://dx.doi.org/10.1186/gb-2009-10-9-239

Randerson-Moor J. A., Harland M., Williams S., Cithbert-Heavens D., Sheridan E., Aveyard J., Sibley K., Whitaker L., Knowles M., Bishop J. N., Bishop D. T. (2001): A germline deletion of p14ARF but not CDKN2A in a melanoma-neural system tumour syndrome family. Hum. Mol. Genet. 10, 55-62 http://dx.doi.org/10.1093/hmg/10.1.55

Reifenberger G., Collins V. P. (2004): Pathology and molecular genetics of astrocytic gliomas. J. Mol. Med. 82, 656-670 http://dx.doi.org/10.1007/s00109-004-0564-x

Renehan A. G., Zwahlen M., Minder C., O’Dwyer S. T., Shalet S. M., Egger M. (2004): Insulin-like growth factor(IGF)-1, IGF binding protein -3 , and cancer risk: systematic review and meta-regression analysis. Lancet 363, 1346-1353 http://dx.doi.org/10.1016/S0140-6736(04)16044-3

Ricard D., Idbaih A., Ducray F., Lahutte M., Hoang-Xuan K., Delattre J-Y. (2012): Primary brain tumours in adults. Lancet 379, 1984-1996 http://dx.doi.org/10.1016/S0140-6736(11)61346-9

Riemenschneider M. J., Koy T. H., Reifenberger G. (2004): Expression of oligodendrocyte lineage genes in oligodendroglial and astrocytic gliomas. Acta Neuropathol. 107, $277-282$ http://dx.doi.org/10.1007/s00401-003-0809-8

Riemenschneider M. J., Perry A., Reifenberger G. (2006): Histopathological classification and molecular genetics of meningiomas. Lancet Neurol. 5, 1045-1054 http://dx.doi.org/10.1016/S1474-4422(06)70625-1

Robinson G., Parker M., Kranenburg T. A., Lu C., Chen X., Ding L., Phoenix T. N., Hedlund E., Wei L., Zhu X. et al. (2012): Novel mutations target distinct subgroups of medulloblastoma. Nature 488, 43-48 http://dx.doi.org/10.1038/nature11213

Rubenstein J. L., Fridlyand J., Shen A., Aldape K., Ginzinger D., Batchelor T., Treseler P., Berger M., McDermott M., Prados M. et al. (2006): Gene expression and angiotropism in primary CNS lymphoma. Blood 107, 3716-3723 http://dx.doi.org/10.1182/blood-2005-03-0897

Russo V. C., Gluckman P. D., Feldman E. L., Werther G. A. (2005): The insulin-like growth factor system and its pleiotropic functions in brain. Endocr. Rev. 26, 916-943 http://dx.doi.org/10.1210/er.2004-0024

Saharinen P., Eklund L., Pulkki K., Bono P., Alitalo K. (2011): VEGF and angiopoietin signaling in tumor angiogenesis and metastasis. Trends Mol. Med. 17, 347-362 http://dx.doi.org/10.1016/j.molmed.2011.01.015

Sasayama T., Nakamizo S., Nishihara M., Kawamura A., Tanaka H., Mizukawa K., Miyake S., Taniguchi M., Hosoda K., Kohmura E. (2012): Cerebrospinal fluid interleukin-10 is a potentially use- 
ful biomarker in immunocompetent primary central nervous system lymphoma (PCNSL). Neuro-Oncology 14, 368-380 http://dx.doi.org/10.1093/neuonc/nor203

Sauvageot C. M., Kesari S., Stiles C. D. (2007): Molecular pathogenesis of adult brain tumors and the role of stem cells. Neurol. Clinics 25, 891-924 http://dx.doi.org/10.1016/j.ncl.2007.07.014

Schwalbe E. C., Lindsey J. C., Straughton D., Hogg T. L., Cole M., Megahed H., Ryan S. L., Lusher M. E., Taylor M. D., Gilbertson R. J. et al. (2011): Rapid diagnosis of medulloblastoma molecular subgroups. Clin. Cancer Res. 17, 1883-1894 http://dx.doi.org/10.1158/1078-0432.CCR-10-2210

Schwartzbaum J. A., Ahlbom A., Lönn S., Warholm M., Rannug A., Auvinen A., Christensen H. C., Henriksson R., Johansen Ch., Lindholm C., Malmer B., Salminen T., Schoemaker M. J., Swerdlow A. J., Feychting M. (2007): An international casecontrol study of glutathione transferase and functionally related polymorphisms and risk of primary adult brain tumors. Cancer Epidemiol. Biomarkers Prev. 16, 559-565 http://dx.doi.org/10.1158/1055-9965.EPI-06-0918

Sciaccaluga M., D’Alessandro G., Pagani F., Ferrara G., Lopez N., Warr T., Gorello P., Porzia A., Mainiero F., Santoro A., Esposito V., Cantore G., Castigli E., Limatola C. (2013): Functional cross talk between CXCR4 and PDGFR on glioblastoma cells is essential for migration. PLoS One 8, e73426 http://dx.doi.org/10.1371/journal.pone.0073426

Shete S., Hosking F. J., Robertson L. B. (2009): Genome-wide association study identifies five susceptibility loci for glioma. Nat. Genet. 41, 899-904 http://dx.doi.org/10.1038/ng.407

Simon M., Voss D., Park-Simon T. W., Mahlberg R., Koster G. (2006): Role of p16 and p14ARF in radio- and chemosensitivity of malignant gliomas. Oncol. Rep. 16, 127-132

Simon M., Hosking F. J., Marie Y., Gousias K., Boisselier B., Carpentier C., Schramm J., Mokhtari K., Hoang-Xuan K., Idbaih A. et al. (2010): Genetic risk profiles identify different molecular etiologies for glioma. Clin. Cancer Res. 16, 5252-5259 http://dx.doi.org/10.1158/1078-0432.CCR-10-1502

Sjöström S., Anderson U., Liu Y., Brännström T., Broholm H., Johansen Ch., Collatz-Laier H., Henriksson R., Bondy M., Melin B. (2010): Genetic variation in EGF and EGFR and glioblastoma outcome. Neuro-Oncol. 12, 815-821 http://dx.doi.org/10.1093/neuonc/noq018

Stiles C. D., Rowitch D. H. (2008): Glioma stem cells: a midterm exam. Neuron 58, 832-846 http://dx.doi.org/10.1016/j.neuron.2008.05.031

Stupp R., Hegi M. E. (2007): Neuro-oncology: oligodendroglioma and molecular markers. Lancet Neurol. 6, 10-12 http://dx.doi.org/10.1016/S1474-4422(06)70663-9

Takei H., Bhattacharjee M. B., Rivera A., Dancer Y., Powell S. Z. (2007): New immunohistochemical markers in the evaluation of central nervous system tumors. Arch. Pathol. Lab. Med. 131, 234-239

Taylor M. D., Northcott P. A., Korshunov A., Remke M., Cho Y. J., Clifford S. C., Eberhart C. G., Parsons D. W., Rutkowski S., Gajar A. et al. (2012): Molecular subgroups of medulloblastoma: the current consensus. Acta Neuropathol. 123, 465-472 http://dx.doi.org/10.1007/s00401-011-0922-z
Tchaicha J. H., Reyes S. B., Shin J., Hossain M. G., Lang F. F., McCarty J. H. (2011): Glioblastoma angiogenesis and tumor cell invasiveness are differentially regulated by $\beta 8$ integrin. Cancer Res. 71, 6371-6381 http://dx.doi.org/10.1158/0008-5472.CAN-11-0991

The Cancer Genome Atlas Network(2008): Comprehensive genomic characterization defines human glioblastoma genes and core pathways. Nature 455, 1061-1068 http://dx.doi.org/10.1038/nature07385

Thomasova D., Mulay S. R., Bruns H., Anders H.-J. (2012): p53 -Independent Roles of MDM2 in NF- $\kappa$ B Signaling: Implications for Cancer Therapy, Wound Healing, and Autoimmune Diseases. Neoplasia 14, 1097-1101

Toedt G., Barbus S., Wolter M., Felsberg J., Tews B., Blond F., Sabel M. C., Hofmann S., Becker N., Hartmann C. et al. (2011): Molecular signatures classify astrocytic gliomas by IDH1 mutation status. Int. J. Cancer. 128, 1095-1103 http://dx.doi.org/10.1002/ijc.25448

Torp S. H., Lindboe C. F., Gronberg B. H., Lydersen S., Sundstrom S. (2005): Prognostic significance of Ki-67/MIB-1 proliferation index in meningiomas. Clin. Neuropathol. 24, 170-174

Van den Bent M. J. (2004): Diagnosis and management of oligodendroglioma. Semin. Oncol. 31, 645-652 http://dx.doi.org/10.1053/j.seminoncol.2004.07.006

Van den Bent M. J., Carpentier A. F., Brandes A. A., Sanson M., Taphoorn M. J. B., Bernsen H. J. J. A., Frenay M., Tijssen C. C., Grisold W., Sipos L. et al. (2006): Adjuvant procarbazine, lomustine, and vincristine improves progression-free survival but not overall survival in newly diagnosed anaplastic oligodendrogliomas and oligoastrocytomas: A randomized European Organisation for Research and Treatment of Cancer phase III trial. J. Clin. Oncol. 24, 2715-2722 http://dx.doi.org/10.1200/JCO.2005.04.6078

Vauleon E., Auger N., Benouaich-Amiel, A., Laigle-Donadey F., Kaloshi G. (2007): The $61 \mathrm{~A} / \mathrm{G}$ polymorphism is functional but is neither a prognostic marker nor a risk factor for glioblastoma. Cancer Genet. Cytogenet. 172, 33-37

http://dx.doi.org/10.1016/j.cancergencyto.2006.07.013

Velnar T., Smrdel U., Popovic M., Bunc G. (2010): Genetic markers in oligodendroglial tumours. Radiol. Oncol. 44, 13-18 http://dx.doi.org/10.2478/v10019-010-0007-y

Viapiano M. S., Hockfield S., Matthews R. T. (2008): BEHAB/ brevican requires ADAMTS-mediated proteolytic cleavage to promote glioma invasion. J. Neurooncol. 88, 261-272 http://dx.doi.org/10.1007/s11060-008-9575-8

Volavsek M., Lamovec J., Popovic M. (2009): Extraneural metastases of anaplastic oligodendroglial tumors. Pathol. Res. Pract. 205, 502-507 http://dx.doi.org/10.1016/j.prp.2008.11.003

Von Deimling A., Korshunov A., Hartmann C. (2011): The next generation of glioma biomarkers: MGMT methylation, BRAF fusions and IDH1 mutations. Brain Pathol. 21, 74-87 http://dx.doi.org/10.1111/j.1750-3639.2010.00454.x

Vousden K. H., Prives C. (2009): Blinded by the light: the growing complexity of p53. Cell 137, 413-431 http://dx.doi.org/10.1016/j.cell.2009.04.037

Wade M., Wang Y. V., Wahl G. M. (2010): The p53 orchestra: Mdm2 and Mdmx set the tone. Trends Cell. Biol. 20, 299-309 
http://dx.doi.org/10.1016/j.tcb.2010.01.009

Waha A., Waha A., Koch A., Meyer-Puttlitz B., Weggen S., Sörensen N., Tonn J., Albrecht S., Goodyer C. G., Berthold F., Wiestler O., Pietsch T. (2003): Epigenetic silencing of the HIC-1 gene in human medulloblastomas. J. Neuropathol. Exp. Neurol. 62, 1192-1201

Walker C., Baborie A., Crooks D., Wilkins S., Jenkinson M. D. (2011): Biology, genetics and imaging of glial cell tumours. Br. J. Radiol. 84, 90-106 http://dx.doi.org/10.1259/bjr/23430927

Wang A. L., Liu Z. X., Li G., Zhang L. W. (2011): Expression and significance of $\mathrm{P} 53$ protein and MDM-2 protein in human gliomas. Chin. Med. J. (Engl). 124, 2530-2533

Weller M., Felsberg J., Hartmann C., Berger H., Steinbach J. P., Schramm J., Westphal M., Schackert G., Simon M., Tonn J. C. et al. (2009): Molecular predictors of progression-free and overall. Survival in patients with newly diagnosed glioblastoma: a prospective translational study of the German glioma network. J. Clin. Oncol. 27, 5743-5750 http://dx.doi.org/10.1200/JCO.2009.23.0805

Wen P. Y., Kesari S. (2004): Malignant gliomas. Curr. Neurol. Neurosci. Rep. 4, 218-227 http://dx.doi.org/10.1007/s11910-004-0042-4

Wen P. Y., Quant E., Drappatz J., Beroukhim R., Norden A. D. (2010): Medical therapies for meningiomas. J. Neurooncol. 99, 365-378 http://dx.doi.org/10.1007/s11060-010-0349-8

Wiedemeyer W. R., Dunn I. F., Quayle S. N., Zhang J., Chheda M. G., Dunn G.P., Zhuang L., Rosenbluh J., Chen S., Xiao Y., Shapiro G. I., Hahn W. C., Chin L. (2010): Pattern of retinoblastoma pathway inactivation dictates response to CDK4/6 inhibition in GBM. Proc. Natl. Acad. Sci. USA 107, 11501-11506 http://dx.doi.org/10.1073/pnas.1001613107

Wrensch M., Minn Y., Chew T., Bondy M., Berger M. S. (2002): Epidemiology of primary brain tumors: Current concepts and review of the literature. Neuro-oncol. 4, 278-299

Wrensch M., Jenkins R. B., Chang J. S. (2009): Variants in the CDKN2B and RTEL1 regions are associated with high-grade glioma susceptibility. Nat. Genet. 41, 905-908 http://dx.doi.org/10.1038/ng.408

Yamasaki F., Yoshioka H., Hama S., Sugiyama K., Arita K., Kurisu K. (2000): Recurrence of meningiomas. Cancer 89, 1102-1110 http://dx.doi.org/10.1002/1097-0142(20000901)89:5<1102:: AID-CNCR20>3.0.CO;2-L

Yan H., Parsons D. W., Jin G., McLendon R., Rasheed A., Yuan W., Kos I., Batinic-Haberle I., Jones S., Riggins G. J. et al. (2009): IDH1 and IDH2 mutations in gliomas. N. Engl. J. Med. 360, $765-773$ http://dx.doi.org/10.1056/NEJMoa0808710

Yao Y., Mack S. C., Taylor M. D. (2011): Molecular genetics of ependymoma. Chin. J. Cancer 30, 669-681 http://dx.doi.org/10.5732/cjc.011.10129

Yew A., Trang A., Nagasawa D. T., Spasic M., Choy W., Garcia H. M., Yang I. (2013): Chromosomal alterations, prognostic factors, and targeted molecular therapies for malignant meningiomas. J. Clin. Neurosci. 20, 17-22 http://dx.doi.org/10.1016/j.jocn.2012.02.007

Yue W. Y., Sai K., Wu Q. L., Xia Y. F., Yu S. H., Chen Z. P. (2012): Long-term molecular changes in WHO grade II astrocytomas following radiotherapy. Chin. J. Cancer 31, 159-165 http://dx.doi.org/10.5732/cjc.011.10149

Zhang J. N., Yi S. H., Zhang X. H., Liu X. Y., Mao Q., Li S. Q., Xiong W. H., Qiu Y. M., Chen T., Ge J. W. (2012): Association of p53 Arg72Pro and MDM2 SNP309 polymorphisms with glioma. Genet. Mol. Res. 11, 3618-3628 http://dx.doi.org/10.4238/2012.October.4.9

Zhao S., Lin Y., Xu W., Jiang W., Zha Z., Wang P., Yu W., Li Z., Gong L., Peng Y., Ding J., Lei Q., Guan K. L., Xiong Y. (2009): Glioma-derived mutations in IDH1 dominantly inhibit IDH1 catalytic activity and induce HIF-1alpha. Science 324, 261-265 http://dx.doi.org/10.1126/science.1170944

Zhao T., Xu Y. (2010): p53 and stem cells: new developments and new concerns. Trends in Cell Biology 20, 170-175 http://dx.doi.org/10.1016/j.tcb.2009.12.004

Received: March 25, 2013

Final version accepted: February 7, 2014 